\title{
Prevention of Illicit Trade in Tobacco Products: Experience of Lithuania
}

\author{
Gintaras Švedas
}

\section{Contents}

1 National Legal Framework Related to Illicit Trade in Tobacco Products .............. 108

1.1 Substantive Law Issues Concerning Illicit Trade in Tobacco Products ........... 108

1.2 Administrative Penalties and Administrative Measures for Illicit Trade in Tobacco

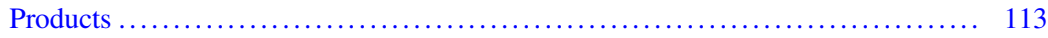

1.3 Punishments and Penal Measures for Illicit Trade in Tobacco Products .......... 114

1.4 Criminal and Administrative Liability of Legal Persons for Illicit Trade in Tobacco

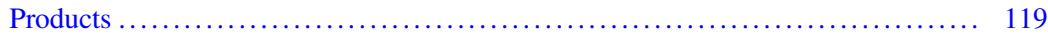

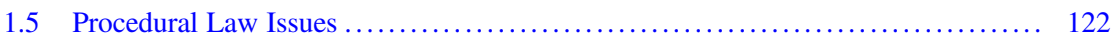

2 Criminological Data ................................................... 127

2.1 General Data on Registered Crimes of Illicit Trade in Tobacco Products .......... 127

2.2 Data on Punishments and Measures (Penal and Others) Applied with Regard to Offenders of Illicit Trade in Tobacco Products ........................... 129

2.3 Short Description of the Most Interesting and/or Exemplary Case Studies with Regard to Illicit Trade in Tobacco Products ........................ 130

2.4 Characteristics of Perpetrators of Illicit Trade in Tobacco Products in Lithuania (Age, Gender, Education, Nationality/Citizenship, Prior Criminal Record, Other

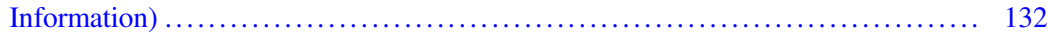

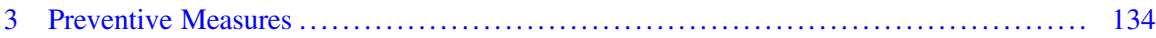

3.1 Measures Relating to Track and Tracing System ......................... 135

3.2 Measures Relating to the Reduction of Demand for Tobacco ................. 135

3.3 Measures Relating to the Reduction of the Supply of Tobacco ............... 137

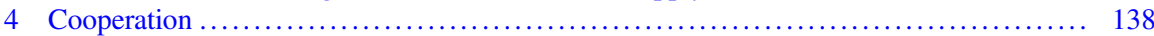

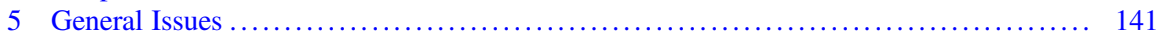

5.1 Rates of Excise Duties on Cigarettes, Cigars, Cigarillos and Smoking Tobacco . . 141

5.2 Main Social, Political and Geographical Factors Which Contribute to the Illicit

Trade in Tobacco Products in Lithuania .............................. 141

6 Conclusion. Identification of Best Practices at the National Level .................. 142

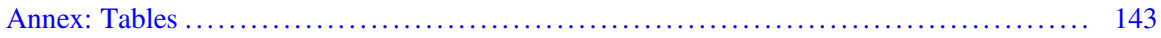

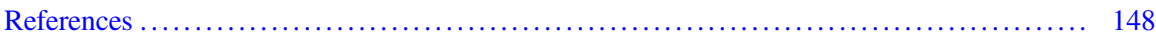

\footnotetext{
G. $\breve{S} v e d a s(\bowtie)$

Department of Criminal Justice, Faculty of Law, University of Vilnius, Vilnius, Lithuania e-mail: gintaras.svedas@tf.vu.lt
} 


\begin{abstract}
The chapter deals with Lithuanian legal framework related to illicit trade in tobacco products, criminological data and preventive measures on illicit trade in tobacco products in Lithuania. Also, various aspects of cooperation matters concerning control and prevention of the illicit trade of tobacco products in Lithuania.
\end{abstract}

\title{
1 National Legal Framework Related to Illicit Trade in Tobacco Products
}

\subsection{Substantive Law Issues Concerning Illicit Trade in Tobacco Products}

The Seimas (Parliament) of Lithuania ratified the WHO Framework Convention on Tobacco Control (hereinafter-FCTC) on 28 September $2004 \mathrm{~m}$. by the Law on Ratification of the WHO Framework Convention on Tobacco Control No. IX-2460 (The Parliament of the Republic of Lithuania 2004b). Furthermore, the WHO FCTC Protocol to Eliminate Illicit Trade in Tobacco Products (hereinafterProtocol) was ratified on 3 November 2016 by the Law on Ratification of the WHO Framework Convention on Tobacco Control Protocol to Eliminate Illicit Trade in Tobacco Products No. XII-2732 (The Parliament of the Republic of Lithuania 2016b). The Protocol has not come into force in Lithuania yet. An expert assessment of national laws leads to the general conclusion that all acts mentioned as unlawful in the WHO Framework Convention on Tobacco Control and its Protocol to Eliminate Illicit Trade in Tobacco Products are recognised as illegal under the Criminal Code of Lithuania (The Parliament of the Republic of Lithuania 2000b) (hereinafter-CC) and Code of Administrative Offences (The Parliament of the Republic of Lithuania 2015) (hereinafter-CAO) in the Lithuanian legal system. In Lithuania, all illegal acts, depending on factual circumstances, may be qualified as (a) smuggling (administrative offence ${ }^{1}$ or crime $^{2}$ ), (b) deceit of

\footnotetext{
${ }^{1}$ Smuggling is an administrative offence when a person "transporting across the state border of Lithuania items, money, works of art or other goods (except movable cultural properties or antiques, substances indicated in the laws on control of certain doping substances, firearms, ammunition, explosives, explosive, radioactive materials or other strategic goods, toxic, highly active, narcotic or psychotropic substances or precursors of narcotic or psychotropic substances) which must be declared at customs and whose value does not exceed 150 BAPP, fails to go through customs control or otherwise avoids this control or transports the mentioned products across the state border of Lithuania without authorisation".

${ }^{2}$ Smuggling is a crime when "a person who, when transporting across the state border of Lithuania items which must be declared at customs and whose value exceeds the amount of 150 BAPP, fails to go through customs control or otherwise avoids this control or transports the mentioned objects across the state border of the Republic of Lithuania without authorisation".
} 
customs (crime), ${ }^{3}$ (c) unlawful possession of goods subject to excise duties (administrative offence ${ }^{4}$ or crime ${ }^{5}$ ), (d) unlawful failure to bring goods or products outside the Republic of Lithuania (crime), ${ }^{6}$ (e) unauthorised engagement in economic, commercial, financial or professional activities (crime), ${ }^{7}$ unlawful activities of a legal person (crime), ${ }^{8}$ use of another's trademark or service mark (crime), ${ }^{9}$ etc. It should be noted that the Lithuanian legal system, while establishing liability for the above-mentioned acts, does not exclude tobacco products as an object of administrative offences or crimes.

Liability for the smuggling (of tobacco products) may be administrative or criminal. The specific kind of liability depends on the value of smuggled tobacco products, which shall be calculated according to their customs value, including taxes to be paid (Art. 212, CC and Art. 208, CAO). It should be noted that according to a resolution of the Government of Lithuania, passengers arriving to Lithuania by air are allowed to legally import 200 cigarettes, and those arriving not by air/by land from third countries - 40 cigarettes (The Government of the Republic of Lithuania 2004). Furthermore, the value of smuggled tobacco products is also a basis for the differentiation of criminal and administrative liability. The threshold separating administrative and criminal liability is 150 basic units of punishment and penalty

\footnotetext{
${ }^{3}$ Deceit of customs is a crime when "a person who brings items from a Member State of the European Union (EU) into Lithuania, which must be declared at customs and whose value exceeds the amount of 150 BAPP, and fails to go through the customs control of Lithuania or another Member State of the EU or otherwise avoids this control".

${ }^{4}$ Unlawful possession of goods subject to excise duties is an administrative offence when "the acquisition of excise goods (except for energy products and electricity), storage, transport, use or disposal in violation of established procedures, trade in excise goods without stamps or other special marks, or stamps of the old model when illegally acquired, held, transported, used or the value of the goods sold does not exceed 150 BAPP”.

${ }^{5}$ Unlawful possession of goods subject to excise duties is a crime when "a person who, in violation of the established procedure, acquires, stores, transports, forwards, uses or handles the goods subject to excise duties whose value exceeds the amount of 150 BAPP".

${ }^{6}$ Unlawful failure to bring goods or products outside the Republic of Lithuania is a crime when "a person who unlawfully fails to bring beyond the state border of Lithuania goods or products whose value exceeds the amount of 150 BAPP, but does not exceed the amount of 250 BAPP, and which ought to have been brought outside Lithuania according to transit or export documents".

${ }^{7}$ Unauthorised engagement in economic, commercial, financial or professional activities is a crime when "a person who undertakes economic, commercial, financial or professional activities in the form of business or, on a large scale, without holding a licence/authorisation to engage in activities for which it is required or by other unlawful means, also a person who engages in prohibited economic, commercial, financial or professional activities".

${ }^{8}$ Unlawful activities of a legal person is a crime when "a person who, on a large scale, engages in activities not provided for in the founding documents of a public legal entity, also a person who establishes or is in charge of a legal entity used as a cover for unlawful activities".

${ }^{9}$ Use of another's trademark or service mark is a crime when "a person who, without holding authorisation, identifies a large or small quantity of goods with another's trademark or presents them for trade or makes use of another's service mark and thereby causes major or small damage".
} 
(hereinafter-BAPP): ${ }^{10}$ criminal liability arises when the value reaches the indicated amount. Administrative liability is differentiated:

- when the value is up to 5 BAPP (Part 1, Art. 208, CAO): fine from $€ 200$ to $€ 1120$;

- when the value is from 5 to 50 BAPP (Part 2, Art. 208, CAO): fine from $€ 1820$ to $€ 4000$;

- when the value is from 50 to 150 BAPP (Part 3, Art. 208, CAO): fine from $€ 3500$ to $€ 6000$.

Criminal liability is also differentiated:

- when the value is from 150 up to 250 BAPP (Part 1, Art. 199, CC), smuggling is considered a general corpus delicti (less serious crime), punishable by a fine from 100 up to 4000 BAPP ( $€ 5000-€ 200,000)$ or custodial sentence up to 4 years;

- when the value exceeds 250 BAPP (Part 3, Art. 199, CC), smuggling is considered a qualified corpus delicti (serious crime), punishable by a fine from 150 to 6000 BAPP (€7500-€300,000) or custodial sentence up to 8 years.

Liability for unlawful possession of goods subject to excise duties also may be administrative or criminal. Responsibility arises depending on the customs value of cigarettes, which does not include the legally held quantity of tobacco products (The Supreme Court 2007b). According to the rules approved by the Minister of Economy, natural persons may legally hold and transport [...] tobacco products if they: keep imported tobacco products in Lithuania in quantities not exceeding: (a) 100 packets of cigarettes, 400 cigarillos, 200 cigars, $1 \mathrm{~kg}$ of smoking tobacco when goods are imported from Member States of the EU; (b) 10 packets of cigarettes, 100 cigarillos, 50 cigars, $0.5 \mathrm{~kg}$ of smoking tobacco when goods are imported from other countries than Member States of the EU (The Minister of Economy 2004). The threshold separating administrative and criminal liability is 150 BAPP: criminal liability arises when the value reaches the indicated amount. Administrative liability is differentiated:

- when the value is up to 2 BAPP (Part 1, Art. 209, CAO): a fine from $€ 40$ to $€ 200$; in case of a repeat offence (Part 2, Art. 209, CAO) - fine from $€ 200$ to $€ 1000$;

- when the value is from 2 to 10 BAPP (Part 3, Art. 209, CAO): a fine $€ 400$ to $€ 1900$; in case of a repeat offence (Part 4, Art. 209, CAO) - a fine from $€ 1950$ to $€ 5590$;

- when the value is from 10 to 50 BAPP (Part 5, Art. 209, CAO): a fine from $€ 2000$ to $€ 5590$; in case of a repeat offence (Part 6, Art. 209, CAO) — a fine from $€ 5460$ to $€ 6000$;

- when the value is from 50 to 150 BAPP (Part 7, Art. 209, CAO): a fine from $€ 5200$ to $€ 6000$; in case of a repeat offence (Part 8, Art. 209, CAO) - a fine from $€ 5760$ to $€ 6000$.

${ }^{10} 1$ BAPP is equal to $€ 50$ (The Government of the Republic of Lithuania 2017). 
Criminal liability is also differentiated:

- when the value is from 150 to 250 BAPP (Part 1 , Art. $199^{2}$, CC), the unlawful possession of goods subject to excise duties is considered a general corpus delicti (less serious crime), punishable by a fine from 100 to 4000 BAPP (€5000$€ 200,000)$ or a custodial sentence up to 4 years;

- when the value exceeds 250 BAPP (Part 3, Art. $199^{2}$, CC), the unlawful possession of goods subject to excise duties is considered a qualified corpus delicti (serious crime), punishable by a fine from 150 to 6000 BAPP (€7500-€300,000) or a custodial sentence up to 8 years.

Liability for deceit of customs (Art. $199^{1}, \mathrm{CC}$ ) and unlawful failure to bring goods or products outside the Republic of Lithuania (Art. 200, CC) may be only criminal. Criminal liability is differentiated:

- when the value is from 150 to 250 BAPP, deceit of customs and unlawful failure to bring goods or products outside the Republic of Lithuania (Para 1, Art. 199 1 and 200, CC) are considered a general corpus delicti (less serious crime), punishable by a fine from 100 to 4000 BAPP (€5000-€200,000) or a custodial sentence up to 4 years;

- when the value exceeds 250 BAPP, deceit of customs and unlawful failure to bring goods or products outside the Republic of Lithuania (Part 2, Art. $199^{1}$ and 200, CC) are considered a qualified corpus delicti (serious crime), punishable by a fine from 150 to 6000 BAPP (€7500-€300,000) or a custodial sentence up to 8 years.

Liability for unauthorised engagement in economic, commercial, financial or professional activities (Art. 202, CC), unlawful activities of a legal person (Art. 203, CC), use of another's trademark or service mark (Art. 204, CC) may be only criminal.

According to the Union Customs Code (2013), the Law on excise duties (The Parliament of the Republic of Lithuania 2010) and the Law on Value Added Taxes (The Parliament of the Republic of Lithuania 2002a), as well as the jurisprudence of the Supreme Administrative Court of Lithuania (The Supreme Administrative Court 2012) and regional administrative courts (Kaunas Region Administrative Court 2012), when smuggled tobacco products are seized in Lithuania, additional financial sanctions - custom duties, excise duties and VAT - are applied. It should be noted that liability under financial law (above-mentioned financial sanctions) can and must be imposed with both criminal and administrative liability for committed crimes (smuggling, deceit of customs, unlawful possession of goods subject to excise duties) or administrative offenses (smuggling or unlawful possession of goods subject to excise duties).

The Constitution, the CC, the CAO and the Code of Criminal Procedure (The Parliament of the Republic of Lithuania 2002b) (hereinafter-CCP) determine the principle of non bis in idem, which means the prohibition of punishing a person for the same violation of law twice. When explaining this constitutional principle, the Constitutional Court of Lithuania has noted in several cases that the prohibition on 
punishing twice for the same (criminal) act "means a prohibition on punishing twice for the same act that is contrary to law, i.e. for the same crime, as well as for the same violation of law which is not a crime. The above-mentioned constitutional principle does not mean that different kinds of liability may not be applied to the person for the violation of law. In itself, the constitutional principle non bis in idem does not deny the possibility of applying more than one sanction of the same kind (i.e. defined by the norms of the same branch of law) to a person for the same violation, i.e. the main and additional punishment or the main and additional administrative penalty" (The Constitutional Court 2001). Furthermore, the Constitutional Court of Lithuania has emphasized that "the constitutional principle non bis in idem also means, inter alia, that if a person who has committed an act which is contrary to law has been held administratively but not criminally liable, i.e. a sanction was imposed on him/her - a penalty not for a crime but for an administrative violation of law - he/she cannot be held criminally liable for the said act" (The Constitutional Court 2005). Thus, the principle of non bis in idem refers only to the relationship between criminal and administrative offenses law.

Statistics of criminal cases and the opinions of experts ${ }^{11}$ show that smuggling, unlawful possession of goods subject to excise duties and unlawful failure to bring goods or products outside the Republic of Lithuania are, as a rule, committed in conjunction with the bribery (passive corruption) of a customs official (Art. 225, CC), abuse of office of a customs official (Art. 228, CC), forgery of a document or possession of a forged document (Art. 300, CC), illicit enrichment (Art. 189 ${ }^{1}$, CC), money laundering (Art. 216, CC), etc. Smuggling, unlawful possession of goods subject to excise duties and unlawful failure to bring goods or products outside the Republic of Lithuania are most commonly committed in complicity in the forms of a group of accomplices and organized group (in some instancescriminal association). It should be noted that criminal association consists of separate corpus delicti of the crime, provided for in Art. 249, CC.

When the illicit trade in tobacco products is committed as a part of a larger-scale crime, the situation, according to the jurisprudence of the Supreme Court of Lithuania, should be defined as a concurrence of criminal acts (real concurrence). Real concurrence of criminal acts occurs if the offender performs more than one criminal act provided for in the same or different articles of the Special Part of the CC by committing more real acts. The Lithuanian criminal law provides special sentencing rules when several criminal acts (concurrence of criminal acts) have been committed. It should be noted that in this situation, the final combined punishment may consist of two punishments. Where several criminal acts are committed, a court shall impose a punishment for each criminal act separately and subsequently — a final combined punishment.

\footnotetext{
${ }^{11}$ Prosecutor (Prosecutor General Office), pre-trial investigator (Customs Criminal Service) and representative of the criminal intelligence unit (Customs Criminal Service).
} 


\subsection{Administrative Penalties and Administrative Measures for Illicit Trade in Tobacco Products}

The CAO provides that in case of violation of the procedure for providing information on tobacco products or related products (Art. 70, CAO), purchase or other transfer of tobacco products to minors (Art. 77, CAO), violation of the licensing procedure for the production, import and marketing of tobacco or related products (Art. 132, CAO), violation of trade in tobacco products by trade and public catering companies (Art. 170, CAO), smuggling (Art. 208, CAO), acquisition of excise goods (except for energy products and electricity), storage, transport, use or disposal in violation of established procedures (Art. 209, CAO), violation of restrictions of consumption or possession of tobacco products or related products (Art. 492, CAO), etc. an administrative penalty—administrative fine from $€ 200$ up to $€ 6000$ - must be imposed. Additionally, in the case of smuggling (Art. 208, CAO), acquisition of excise goods (except for energy products and electricity), storage, transport, use or disposal in violation of established procedures (Art. 209, CAO), violation of restrictions of consumption or possession of tobacco products or related products (Art. 492, CAO), etc., an administrative measure-administrative confiscation of property (smuggled goods, excise goods used or disposed in violation of established procedures, tobacco products, etc.) —also must be imposed; in case of violation of rules on trade in tobacco products by trade and public catering companies (Art. 170, CAO) - administrative confiscation of the tobacco products may be imposed. Furthermore, in the case of smuggling (Art. 208, CAO) and acquisition of excise goods (except for energy products and electricity), storage, transport, use or disposal in violation of established procedures (Art. 209, CAO), administrative confiscation of transport or other means for smuggling or transport or other means for transportation of excise goods must be imposed.

Article 25 of the CAO states that a fine is a pecuniary administrative penalty imposed in the cases provided for in the Special Part of the CAO. According to the $\mathrm{CAO}$, the minimum amount of a fine shall be not less than $€ 10$, and the maximum amount of a fine shall be not more than $€ 6000$. Sanctions of the Articles of the Special Part of the CAO provide the minimum and maximum amounts of fines imposed following an administrative offence. In the cases and procedures provided for in the CAO, a fine or a part thereof may be replaced by community service.

Administrative confiscation of property is an administrative measure, which may be imposed together with an administrative penalty by the court or the administrative case investigating authority (official). The confiscation of property subject to legal registration under Lithuanian legislation may be ordered only by a court. According to Art. 29 of the CAO, the "confiscation of property shall be the compulsory uncompensated taking into the ownership of the state of any form of property subject to confiscation and held by the offender or other persons".

An instrument or a means used to commit an administrative offence, including the object and result of such an act, shall be considered as property subject to confiscation. Property of any form directly or indirectly obtained from an act prohibited by 
the CAO shall be considered as the result of the act. Confiscation of property may be imposed in the cases provided for in the article of the Special Part of the CAO which establishes administrative responsibility for an act committed by a person. Items that are banned from circulation are confiscated in all cases. Only items that are the property of the offender may be confiscated. This general rule has an exception according to which, in the case of administrative offences provided for in a special list (which includes, inter alia, smuggling (Art. 208, CAO), acquisition of excise goods (except for energy products and electricity), storage, transport, use or disposal in violation of established procedures (Art. 209, CAO), etc.), property subject to confiscation may be confiscated irrespective of whether the natural or legal person is owner of that property, in cases where: (1) when transferring the property to the offender or other persons, he/she was or ought to have been aware that this property would be used for the commission of the administrative offence; (2) the property has been transferred thereto under a fictitious transaction; (3) the property has been transferred thereto as to a family member or close relative of the offender; (4) the property has been transferred to him/her as to a legal person, and the offender, his/her family members or close relatives is/are the legal person's manager, a member of its management body or participants holding at least $50 \%$ of shares in the legal person (member shares, contributions, etc.); (5) when acquiring the property, he/she or the persons holding managerial positions in the legal person and being entitled to represent it, to make decisions on behalf of the legal person or to control the activities of the legal person was/were or ought to and could have been aware that the property is an instrument or a means used to commit an administrative offence, and/or the object or result of such an act.

\subsection{Punishments and Penal Measures for Illicit Trade in Tobacco Products}

Lithuanian criminal law foresees three forms of implementation of criminal liability of a natural or legal person for the commission of a criminal act: (1) imposition of a punishment; (2) release from criminal liability with application of penal or reformative measures or without them; (3) suspension (partial suspension) of the execution of arrest or imprisonment or release from the execution of punishment with application of penal or reformative measures or without them.

The CC provides that:

(a) simple smuggling (Part 1, Art. 199, CC), simple deceit of customs (Part 1, Art. $199^{1}$, CC), simple unlawful possession of goods subject to excise duties (Part 1, Art. $199^{2}$, CC) shall be punished by a fine (from 100 to 4000 BAPP) or by a custodial sentence for a term of up to 4 years;

(b) qualified smuggling (Part 3, Art. 199, CC), qualified deceit of customs (Part 2 , Art. $199^{1}$, CC), qualified unlawful possession of goods subject to excise duties 
(Part 2, Art. $199^{2}$, CC) shall be punished by a fine (from 150 to 6000 BAPP) or by a custodial sentence for a term of up to 8 years;

(c) simple unlawful failure to bring goods or products outside the Republic of Lithuania (Part 1, Art. 200, CC), prohibited activities (Part 2, Art. 202, CC) shall be punished by a custodial sentence for a term of up to 4 years;

(d) qualified unlawful failure to bring goods or products outside the Republic of Lithuania (Part 2, Art. 200, CC) shall be punished by a custodial sentence for a term of up to 8 years;

(e) unauthorised engagement in economic, commercial, financial or professional activities (Part 1, Art. 202, CC) shall be punished by community service or a fine (from 100 to 4000 BAPP), or by restriction of liberty, or by a custodial sentence for a term of up to 4 years;

(f) unlawful activities of a legal entity (Part 1, Art. 203, CC) shall be punished by a fine, by arrest or by a custodial sentence for a term of up to 1 year; qualified unlawful activities of a legal person (Part 2, Art. 203, CC) shall be punished by a fine (from 50 to 2000 BAPP), by arrest or by a custodial sentence for a term of up to 2 years;

(g) use of another's trademark or service mark (Part 1, Art. 204, CC) shall be punished by a fine (from 50 to 2000 BAPP), by restriction of liberty, or by a custodial sentence for a term of up to 2 years.

A fine is a pecuniary punishment imposed by a court in the cases provided for in the Special Part of the CC. Article 47 of the CC provides that a fine is calculated in BAPP. The maximum amount of a fine shall be determined as follows: (1) for a misdemeanour-from 15 to 500 BAPP; (2) for a minor crime-from 50 to 2000 BAPP; (3) for a less serious crime-from 100 to 4000 BAPP; (4) for a serious crime-from 150 to 6000 BAPP; (5) for a negligent crime-from 20 to 750 BAPP. A minor may be subject to a fine in an amount from 5 to 50 BAPP. A fine may be imposed only against a minor already employed or possessing his/her own property. The concrete amount of a fine for a committed criminal act shall be specified by the court when imposing the punishment.

Where a person does not possess sufficient funds to pay a fine imposed by a court, the court may (with the convict's consent) replace this punishment with community service. Where a person evades voluntary payment of a fine and it is not possible to recover it, a court may replace the fine with restriction of liberty.

Arrest shall mean a short-term custodial sentence served in a short-term detention facility. Article 49 of the CC provides that arrest shall be imposed by a court in the cases provided for in the Special Part of the CC. Arrest shall be imposed for a period from 15 to 90 days for a crime and from 10 to 45 days for a misdemeanour. The term of arrest for a criminal act shall be specified by the court when imposing the punishment. Arrest shall not be imposed upon pregnant women and may be not imposed upon persons raising a child under the age of 3 years, taking into consideration the interests of the child.

Fixed-term imprisonment is compulsory isolation of the offender from society in special state institutions. Article 50 of the $\mathrm{CC}$ provides that fixed-term imprisonment 
may be imposed by a court in the cases provided for in the Special Part of the CC. Fixed-term imprisonment may be imposed for a period from 3 months to 20 years. In the case of imposition of such a punishment, when a new crime is committed before a sentence for a previous crime is served, imprisonment for a period of up to 25 years may be imposed. In the event of imposition of imprisonment upon a minor, the minimum punishment shall be equal to one-half of the minimum punishment provided for by the sanction of the article of the Special Part of the CC under which the minor is prosecuted. The maximum period of imprisonment in respect of a minor may not exceed 10 years.

It should be noted that in the case of simple smuggling (Part 1, Art. 199, CC), simple deceit of customs (Part 1, Art. 199 ${ }^{1}$, CC), simple unlawful possession of goods subject to excise duties (Part 1, Art. $199^{2}, \mathrm{CC}$ ), simple unlawful failure to bring goods or products outside the Republic of Lithuania (Part 1, Art. 200, CC), prohibited activities (Part 2, Art. 202, CC), unauthorised engagement in economic, commercial, financial or professional activities (Part 1, Art. 202, CC) unlawful activities of a legal entity (Part 1, Art. 203, CC), use of another's trademark or service mark (Part 1, Art. 204, CC), the offender may be released from criminal liability (with application or without application of penal measures). Release from criminal liability means that a natural or legal person which has committed a criminal act is released from the main consequences of criminal liability (e.g. imposition of the punishment). Chapter VI "Release from Criminal Liability" and Chapter XI "Peculiarities of Criminal Liability of Minors" of the General Part of the CC provides for adults 7 types of release from criminal liability, which may be conditional or unconditional, and 1 type of unconditional release from criminal liability for minors.

Furthermore, in the case of the above-mentioned crimes the court may order the suspension (partial suspension) of the execution of a punishment (arrest or fixedterm imprisonment). Article 75 of the $\mathrm{CC}$ provides rules concerning suspension of the execution of a punishment. First of all, where a person is subject to arrest, the court may suspend the execution of the imposed sentence for a period ranging from 3 months to 1 year and impose intensive supervision. Secondly, where a person is subject to a custodial sentence for a term of up to 6 years for one or several crimes committed through negligence or to a custodial sentence for a term of up to 4 years for the commission of one or several premeditated crimes (except for grave crimes), the court may suspend the execution of the imposed sentence for a period ranging from 1 to 3 years. Thirdly, where a person is subject to a custodial sentence for a term of more than 6 years for crimes committed through negligence, or to a custodial sentence for a term of more than 5 years for minor or less serious premeditated crimes, or to a custodial sentence for a term of up to 5 years for a serious crime, the court may impose a partial suspension of the execution of the sentence for a period ranging from 1 to 3 years. The execution of the sentence may be suspended (partially suspended) where the court rules that there is a reasonable ground for believing that the purpose of the punishment will be achieved without the sentence actually being served. In suspending the execution of the sentence, the court shall impose upon the convict one or more mutually compatible penal measures and/or obligations: (1) to 
offer an apology to the victim; (2) to provide assistance to the victim during the victim's medical treatment; (3) to undergo treatment for addiction to diseases, where the convict agrees; (4) to educate and take care of his/her minor children, to take care of their health, to maintain them; (5) to take up employment or studies, or continue employment or studies; (6) to participate in a programme addressing behaviour; (7) house arrest, unless the need to leave is related to work or studies; (8) not to leave the city/district of the place of residence without the authorisation of the institution supervising the convict; (9) to refrain from visiting certain places or to refrain from communicating with certain persons or groups of persons; (10) to refrain from using psychoactive substances; (11) to refrain from possessing, using or acquiring certain items or from engaging in certain activities.

The court may impose, at the request of the person concerned or other participants of criminal proceedings, also at its own discretion, other obligations not provided for by the criminal law which, in the court's opinion, would have a positive impact on the conduct of the convict. In imposing such penal measures and/or obligations, the court shall specify the time limit for complying therewith.

According to the $\mathrm{CC}$, an adult person released from criminal liability for the commission of a misdemeanour, negligent crime, minor or less serious crime or punishment may be subject to the following penal measures: (1) prohibition on exercising a special right; (2) deprivation of public rights; (3) deprivation of the right to be employed in a certain position or to engage in a certain type of activity; (4) compensation for or remediation of property damage; (5) unpaid work; (6) payment of a contribution to a fund for victims of crime; (7) confiscation of property; (8) the obligation to reside separately from the victim and/or prohibition on approaching the victim closer than a prescribed distance; (9) participation in programmes addressing violent behaviour; and (10) extended confiscation of property.

Prohibition to exercise a special right, deprivation of public rights, deprivation of the right to be employed in a certain position or to engage in a certain type of activity, payment of a contribution to a fund for crime victims, confiscation of property, the obligation to reside separately from the victim and (or) prohibition on approaching the victim closer than a prescribed distance, participation in programmes addressing violent behaviour and extended confiscation of property may be imposed jointly with a punishment.

When imposing two or more penal measures, the compatibility of the measures and the possibility of their corrective effect upon the convicted person must be taken into consideration.

Deprivation of public rights is provided for in Art. $68^{1}$ of the CC, which states that "deprivation of public rights shall be deprivation of the right to be elected or appointed to an elected or appointed position at state or municipal institutions and agencies, undertakings or non-state organisations". The court shall impose deprivation of public rights in cases when a criminal act is committed in abuse of public rights. Public rights may be deprived for a period from 1 to 5 years. When imposing deprivation of public rights, the court shall indicate the right which is being deprived and a specific term for this penal measure. 
Deprivation of the right to be employed in a certain position or to engage in a certain type of activity is provided for in Art. $68^{2}$ of the CC, which states that "the court shall order deprivation of the right to be employed in a certain position or to engage in a certain type of activity in cases when a person commits a criminal act in the field of his occupational or professional activities or where, having regard to the nature of the criminal act committed, the court comes to the conclusion that the person may not preserve the right to be employed in a certain position or to engage in a certain type of activity". This penal measure may be imposed for a period from 1 to 5 years. When ordering deprivation of the right to be employed in a certain position or to engage in a certain type of activity, the court shall indicate the right which is being deprived and a specific term for this penal measure.

Payment of a contribution to a fund for crime victims is provided for in Art. 71 of the CC, which states that "a court may order payment of a contribution in the amount from 5 up to 125 BAPPs for an adult person and from 100 up to 2000 BAPPs for a legal person to a fund for crime victims. The contribution must be paid within a time limit (not to exceed 3 years) laid down by the court.

Confiscation of property is provided for in Art. 72 of the CC, which states that "confiscation of property shall be the compulsory uncompensated taking into the ownership of the state of any form of property subject to confiscation and held by the offender or other persons". An instrument or a means used to commit an act prohibited by the $\mathrm{CC}$ or the result of such an act shall be considered as property subject to confiscation. Property of any form directly or indirectly obtained from an act prohibited by the CC shall be considered as the result of the act.

Property held by the offender and being subject to confiscation must be confiscated in all cases.

Property held by another natural or legal person and being subject to confiscation shall be confiscated irrespective of whether the person has been convicted of the commission of an act prohibited by the CC, where: (1) when transferring the property to the offender or other persons, he/she was or ought to have been aware that this property would be used for the commission of the act prohibited by the $\mathrm{CC}$; (2) the property has been transferred thereto under a fictitious transaction; (3) the property has been transferred thereto as to a family member or close relative of the offender; (4) the property has been transferred to it as to a legal person, and the offender, his/her family members or close relatives is/are the legal person's manager, a member of its management body or participants holding at least $50 \%$ of shares in the legal person (member shares, contributions, etc.); (5) when acquiring the property, he/she or the persons holding management positions in the legal person and being entitled to represent it, to make decisions on behalf of the legal person or to control the activities of the legal person was/were or ought to and could have been aware that the property is an instrument or a means used to commit an act prohibited by the $\mathrm{CC}$ or the result of such an act.

Where the property which is subject to confiscation has been concealed, consumed, belongs to third parties or cannot be taken for other reasons or confiscation of this property would not be appropriate, the court shall recover from the offender or other persons a sum of money equivalent to the value of the property subject to confiscation. 
When ordering confiscation of property, the court must specify the items subject to confiscation or the monetary value of the property subject to confiscation.

Extended confiscation of property is provided for in Art. $72^{3}$ of the CC, which states that "extended confiscation of property shall be the taking into ownership of the State of the property of the offender or part thereof disproportionate to the legitimate income of the offender, where there are grounds for believing that the property has been obtained by criminal means".

Extended confiscation of property shall be imposed provided that all of the following conditions are met: (1) the offender has been convicted of a less serious, serious or grave premeditated crime from which he/she obtained or could have obtained material gain; (2) the offender holds the property acquired during the commission of an act prohibited by the $\mathrm{CC}$, after the commission thereof or within a period of 5 years prior to the commission thereof, whose value does not correspond to the offender's legitimate income, and the difference is greater than 250 BAPP, or transfers such property to other persons within the period specified in this point; (3) the offender fails, in the course of criminal proceedings, to provide proof of the legitimacy of acquisition of the property. This property, if it has been transferred to another natural or legal person, shall be confiscated from this person where at least one of the following grounds exists: (1) the property has been transferred under a fictitious transaction; (2) the property has been transferred to the offender's family members or close relatives; (3) the property has been transferred to a legal person, and the offender, his/her family members or close relatives is/are the legal person's manager, a member of its management body or participants holding at least $50 \%$ of shares in the legal person (member shares, contributions, etc.); (4) the person whereto the property has been transferred or the persons holding managing positions in the legal person and being entitled to represent it, to make decisions on behalf of the legal person or to control the activities of the legal person was/were or ought to and could have been aware that the property has been obtained by criminal means or with illicit funds of the offender.

Where the property or part thereof which is subject to confiscation has been concealed, consumed, belongs to third parties or cannot be taken for other reasons or confiscation of this property would not be appropriate, the court shall recover from the offender or other persons a sum of money equivalent to the value of the property subject to confiscation.

When ordering extended confiscation of property, the court must specify the items subject to confiscation or the monetary value of the property or part thereof subject to confiscation.

\subsection{Criminal and Administrative Liability of Legal Persons for Illicit Trade in Tobacco Products}

The CC of Lithuania provides criminal liability for a legal person, while special laws provide administrative responsibility (economic sanctions) for a legal person having committed an administrative offence. 
Corporate criminal liability was introduced in 2002 for several crimes when Lithuania ratified the Council of Europe Criminal Law Convention on Corruption (1999). The prerequisites for the criminal liability of legal persons stem directly from the aforementioned Convention and EU legal acts. It should be noted that the Constitutional Court, by its decision of 8 June 2009 (The Constitutional Court 2009), has recognised that corporate criminal liability does not expostulate with the Constitution of Lithuania. Also, the Constitutional Court has recognised that corporate criminal liability derives from the liability of a natural person, and this leads to the conclusion that a legal person and a natural person may be subject to criminal liability only for one and the same crime, committed by a natural person (Švedas 2011, p. 98).

A legal person shall be held liable solely for the criminal acts the commission whereof is subject to liability of a legal person as provided for in the Special Part of the CC. Currently, there are up to 110 criminal acts provided for in the $\mathrm{CC}$ for which legal persons may be punished. This list has been composed mostly as a result of the national implementation of international treaties and EU secondary law requirements. This list includes smuggling (Art. 199, CC), deceit of customs (Art. 199 ${ }^{1}$, CC), unlawful possession of goods subject to excise duties (Art. $199^{2}$, CC), unlawful failure to bring goods or products outside the Republic of Lithuania (Art 200, CC), unauthorised engagement in economic, commercial, financial or professional activities (Art. 202, CC), unlawful activities of a legal entity (Art. 203, CC), use of another's trademark or service mark (Art. 204, CC), etc.

The CC provides two grounds for the criminal liability of a legal personmandatory and discretionary. A legal person shall be held mandatorily liable for criminal acts committed by a natural person solely where the criminal act was committed for the benefit or in the interests of the legal person by a natural person acting independently or on behalf of the legal person provided that he/she, while occupying a management position in the legal person, was entitled: (1) to represent the legal person, or (2) to take decisions on behalf of the legal person, or (3) to control the activities of the legal person.

The discretionary ground of the criminal liability of a legal person may be realised in two instances. First, a legal person may be held liable for criminal acts also where they have been committed by an employee or authorised representative of the legal person as a result of insufficient supervision or control by the person occupying a management position in the legal person. Second, a legal person also may be held liable for a criminal act committed by another legal person representing him/her or being under its control, when the criminal act was committed for the benefit of the above-mentioned legal person as a result of an order or permission, or insufficient supervision or control by a person occupying a management position in the legal person. In these cases, a legal person may be prosecuted only when it is held that such liability is reasonable. The prosecutor and the court, when ascertaining whether it is possible to prosecute, should take account of the entity's organizational culture, management principles applicable to the prevention of criminal acts, acceptance of the consequences of the criminal act, the relationship between the legal person and the employee who has committed the criminal act, indicating whether the criminal 
act and consequences may be associated with the legal person, etc. It should be noted that the Constitutional Court has stressed that, although the legal person's guilt is closely related to the individual's guilt, they are not identical. This separation of guilt allowed the Constitutional Court to conclude that the legal person's guilt should be established by law and recognised by an effective court judgement. The Supreme Court of Lithuania has also emphasised that a legal person's guilt should be proved by the methods mentioned in the CCP (The Supreme Court 2010a). In order to hold a legal person guilty, two elements should be present: (1) a relationship between the criminal act of the head of the legal person and the legal person's business strategy (for example, all appropriated money was used for unreported payments, etc.) and (2) the legal person's owner, who is responsible for formulation of strategy and compliance with the duty of care, should promote the illegal conduct, be aware of or at least tolerate such behaviour (for example, recognise the results of the crime $e x$ post facto, etc.) (Švedas 2011, p. 100).

Criminal liability of a legal person does not release from criminal liability a natural person who has committed, organised, instigated or assisted in the commission of the criminal act, nor does the fact that a natural person shall be released from criminal liability or not be held liable for any other reason.

The State, a municipality, a State or municipal institution or agency (for example, the Ministry of Foreign Affairs, Prison Department under the Ministry of Justice, etc.) as well as international public organisation (for example, EU, Council of Europe, etc.) shall not be held liable under the CC of Lithuania.

Article 43 of the $\mathrm{CC}$ provides that the following punishments may be imposed upon a legal person for the commission of a criminal act: (1) a fine; (2) restriction of operation of the legal person; (3) liquidation of the legal person. Having imposed a punishment upon a legal person, a court may also decide to announce this judgement in the media.

According to Art. 47 of the $\mathrm{CC}$, the amount of the fine imposed on a legal person shall be from 200 to 100,000 BAPP. The specific amount of the fine for a committed criminal act shall be specified by the court when imposing the punishment.

Restriction of operation of a legal person is one of the medium-stringency punishments that may be imposed on a legal person. Article 52 of the CC provides that "when imposing the restriction of operation of a legal person, a court shall prohibit the legal person from engaging in certain activities or order it to close a certain division of the legal person". Scholars of Lithuanian criminal law have emphasised that the restriction of operation of a legal person may not be applicable to an internal division of a legal person which is designated to serve the legal person (for example, finance or human resources department, etc.) (Švedas (Ed.) 2004, p. 300). Operation of a legal person may be restricted for a period from 1 to 5 years.

Liquidation of a legal person is the most severe punishment applicable to a legal person. Scholars of Lithuanian criminal law have emphasised that this punishment should be imposed in exceptional cases, where a legal person, for example, acts as a cover for criminal activity (Švedas (Ed.) 2004, p. 301). Article 53 of the CC provides that "when imposing the liquidation of a legal person, a court shall order the legal person to terminate, within the time limit laid down by the court, the entire 
economic, commercial, financial or professional activity and to close all divisions of the legal person".

It should be noted that according to the $\mathrm{CC}$, a legal person may also be subject to payment of a contribution to a fund for crime victims, confiscation of property or extended confiscation of property.

Article 26 of the Law on Control of Tobacco, Tobacco Products and Related Products (The Parliament of the Republic of Lithuania 2003) provides administrative responsibility (economic sanctions) for legal persons and branches of foreign legal persons who commit various infringements of the provisions of the abovementioned law. Economic sanctions consist of a fine from €289 to €8688 and may also include withdrawal of licences. For example, legal persons and branches of foreign legal persons who infringe the prohibitions on sales, storage or shipment of tobacco products and the requirements on the traceability of tobacco products, provided that this does not give rise to criminal liability, shall be subject to a fine in an amount between $€ 2896$ and $€ 8688$ together with the withdrawal of the licence, etc. Moreover, according to Art. 25 of the Law on Control of Tobacco, Tobacco Products and Related Products, confiscated tobacco products shall be destroyed in accordance with the procedure laid down by the Government. The description of the procedure for the destruction of seized tobacco products (The Government of the Republic of Lithuania 1999) determines that seized tobacco products are burned in specially designated places.

\subsection{Procedural Law Issues}

The main institution responsible for the pre-trial investigation of crimes involving illicit trade in tobacco products is the Customs Criminal Service (hereinafter-CCS). It should be noted that customs units of the Customs Department are the main institution for the investigation of administrative offences involving illicit trade in tobacco products. Moreover, the State Border Protection Service (hereinafterSBPS) also has responsibility for the pre-trial investigation of crimes involving illicit trade in tobacco products. The main tasks of the CCS and SBPS (which are both law enforcement agencies) in the area of their competence are: (1) to collect criminal intelligence for disclosing smuggling, deceit of customs, unlawful possession of goods subject to excise duties, unlawful failure to bring goods or products outside Lithuania, and illegal migration; (2) to disclose and investigate crimes and other violations of legal acts related to customs or state border protection service activities; (3) to collect, analyse and evaluate information on the development of trends in the illicit trade in tobacco products, economical, social and criminogenic reasons for the existence and development of illicit trade in tobacco products; and (4) to carry out international and interdepartmental cooperation in the prevention and pre-trial investigation of crimes involving illicit trade in tobacco products or illegal migration, etc. 
According to the CCP and Prosecutor General's recommendation "On the distribution of the pre-trial investigation between the institutions of the pre-trial investigation" (Prosecutor General 2003a), pre-trial investigation of smuggling (Art. 199, CC), deceit of customs (Art. 199 ${ }^{1}$, CC), unlawful possession of goods subject to excise duties (Art. $199^{2}, \mathrm{CC}$ ), and unlawful failure to bring goods or products outside the Republic of Lithuania (Art. 200, CC) is entrusted to the CCS and SBPS. It should be noted that the prosecutor may entrust a pre-trial investigation institution with the investigation of another criminal act even though the pre-trial investigation of such criminal acts is not within the competence of this institution. Furthermore, if necessary, the prosecutor may set up a joint investigation group involving officials of the different pre-trial investigation institutions.

The Lithuanian criminal procedure foresees that all criminal acts (including crimes involving illegal trade of tobacco-smuggling (Art. 199, CC), deceit of customs (Art. $199^{1}$, CC), unlawful possession of goods subject to excise duties (Art. $199^{2}, \mathrm{CC}$ ), and unlawful failure to bring goods or products outside the Republic of Lithuania (Art 200, CC), etc.) are investigated and prosecuted following the same procedures. The legality principle applies to pre-trial investigations and prosecutions in Lithuania, since, in accordance with Art. 2 of the CCP, a prosecutor and a pre-trial investigator must institute criminal proceedings in every case in which the elements of a criminal act come to light and shall take all measures to conduct, as soon as possible, the pre-trial investigation to uncover the criminal act. The CCP specifies that any pre-trial investigation shall be commenced: (1) upon the receipt of a complaint, application or report about a criminal act; (2) upon the receipt of a victim's complaint; and (3) upon establishing elements of a criminal act and the drawing up of an official notice by a prosecutor or pre-trial investigator. When the prosecutor receives a complaint, an application or communication about a criminal act or where the prosecutor himself/herself ascertains the elements of a criminal act, he/she shall initiate a pre-trial investigation at the earliest opportunity. After the start of the pre-trial investigation, the prosecutor either performs the actions of the pre-trial investigation himself/herself or directs a pre-trial investigation institution to perform them. Following the receipt of a complaint, an application or a report, and, where necessary, its updated version, the prosecutor or pre-trial investigator may refuse to commence a pre-trial investigation only where the facts stated in the complaint, application or the report about the criminal act are obviously irrelevant, or circumstances which are set out in the law of the criminal procedure and make the criminal procedure unavailable are evident. It should be noted that in the course of updating a complaint, an application or a report, the prosecutor or pre-trial investigator may gather additional information, for example, by asking the person who filed the complaint, by taking documents from state institutions, etc.

A pre-trial investigation must be carried out in an expedited manner and not later than: (1) 3 months for the investigation of a misdemeanor; (2) 6 months for the investigation of negligent, minor and less serious crimes; (3) 9 months for the investigation of serious and grave crimes. These terms may be extended by the decision of a superior prosecutor due to the complexity, importance or other relevant circumstances of the case. The pre-trial investigation must be a priority in cases 
where suspects are arrested, as well as cases in which the suspects or victims are minors. The pre-trial investigation may be closed under the condition that all necessary pre-trial investigation actions provided for by the CCP have been conducted, and the case has been sufficiently clarified that the prosecutor may decide (a) to file an indictment, or (b) to terminate the pre-trial investigation, or (c) to suspend the pre-trial investigation (the suspension of a pre-trial investigation means a temporary pause of the pre-trial investigation that is not included in the term of the pre-trial investigation ${ }^{12}$ ).

The CCP provides an exhaustive list of admissible means of proof (kinds of evidence): testimony of the suspect and the accused; testimony of the victim; testimony of the witness; expert report; specialist conclusion; item as evidence; document as evidence.

The Lithuanian criminal procedure provides only one type of prosecution, i.e. state prosecution. State prosecution is pursued by the state prosecutor. Where the prosecutor is satisfied that sufficient evidence has been gathered during the pre-trial investigation as to the culpability of the suspect for committing a criminal act, he/she shall notify the suspect, his/her defence counsel, the victim, the plaintiff and the accused in a civil action and their representatives that the pre-trial investigation is finished and that they have a right to examine the case file and make motions for additional pre-trial investigation actions. The prosecutor must issue a reasoned decision on any motions for additional pre-trial investigation actions. Where the pre-trial investigation or the majority of its actions was conducted by a pre-trial investigation institution, the prosecutor may order that the pre-trial investigation institution submit a short written report about the pre-trial investigation it carried out (Prosecutor General 2003b). Afterwards, the prosecutor shall draft an indictment. The indictment shall state: (1) the name of the court which will hear the criminal case; (2) the name, surname, date of birth, marital status, profession, workplace of the suspect and, at the prosecutor's discretion, any other personal information; (3) a brief description of the criminal act: the place, time, forms, motives, consequences and other important circumstances; information about the victim; extenuating or aggravating circumstances for the suspect; (4) the basic information on which the prosecution is based; (5) the article (paragraph and subparagraph) of the $\mathrm{CC}$ establishing liability for the committed act; etc. (Prosecutor General 2015).

The Lithuanian legal system distinguishes two forms of secret data collection. Secret data collection may be performed by state authorities for the purposes of criminal proceedings and for the purposes of national security. Secret data collection for the purposes of national security is regulated by the Law on Intelligence (The Parliament of the Republic of Lithuania 2000a). Meanwhile, secret data collection

\footnotetext{
${ }^{12}$ The Lithuanian criminal procedure currently provides one discretionary ground for the suspension of a pre-trial investigation according to which, when all the necessary pre-trial investigation actions have been carried out and all possibilities to determine the offender have been exhausted, but that person's identity has not been established, a pre-trial investigation may be suspended by the reasoned decision of the prosecutor.
} 
for the purposes of criminal proceedings is provided for in the Law on Criminal Intelligence (The Parliament of the Republic of Lithuania 2012) and CCP. According to the Law on Criminal Intelligence, an investigation involving criminal intelligence shall be started before a pre-trial investigation if: (1) there is information about the preparation of or commission of a serious or grave crime, or of a less serious crime specified in a special list (which includes all crimes involving illegal trade in tobacco-smuggling (Art. 199, CC), deceit of customs (Art. 199 ${ }^{1}$, CC), unlawful possession of goods subject to excise duties (Art. 199 ${ }^{2}, \mathrm{CC}$ ), unlawful failure to bring goods or products outside the Republic of Lithuania (Art. 200, CC); (2) the suspect, accused or convicted is in hiding; (3) the person has disappeared; (4) the protection of individuals from criminal activity is carried out. During a criminal intelligence investigation, state authorities may apply such methods of secret data collection as: (a) questioning; (b) controlled delivery; (c) actions simulating a criminal act; (d) covert surveillance; (e) secret operation; (f) use of technical means, etc. If a criminal intelligence investigation reveals the corpus delicti signs of a criminal act, a pre-trial investigation is immediately initiated (Prosecutor General 2013). The Supreme Court of Lithuania has noted that criminal intelligence must be turned into a pre-trial investigation as soon as possible since the CCP requires the pre-trial investigation and disclosure of the criminal act to be carried out in the shortest time (The Supreme Court 2016).

When the pre-trial investigation is started, the pre-trial judge or prosecutor may order the application of covert (secret) investigative actions provided for in the CCP. The CCP lists these covert (secret) investigative actions: actions of the officers of a pre-trial investigation institution without disclosing their identity (Art. 158, CCP), simulation of a criminal act (Art. 159, CCP) and covert surveillance (Art. 160, CCP). According to the CCP, a prosecutor, upon receiving information from about plans to commit a crime or to participate in such a crime, may file an application with a pre-trial judge to authorise the person to commit actions simulating a criminal act in order to detect persons committing crimes. This measure may be applied only for the crimes provided for in the $\mathrm{CC}$. When performing actions simulating a criminal act, it is prohibited to incite another person to commit a criminal act (The Supreme Court 2007a). This measure is performed by an officer of the pre-trial investigation institution. In special cases, when there are no other possibilities for detecting persons engaged in the commission of crimes, this measure may also be conducted by persons who are not officers of a pre-trial investigation institution. When authorising actions simulating a criminal act, the pre-trial judge must make a ruling specifying the following: (1) the person authorised to commit actions simulating a criminal act; (2) the person against whom such actions are to be performed; (3) information about the criminal act of that person; (4) the authorised actions; (5) the result sought. According to the CCP, actions of the officers of a pre-trial investigation institution without disclosing their identity shall be authorised by a ruling of the pre-trial judge and on condition that there is sufficient information about the criminal activities of the person who is subject to the pre-trial investigation. These officers may also engage in conduct simulating a criminal act. If such actions restrict the inviolability of the home or the secrecy of correspondence, they may be 
applied only when investigating less serious, serious and grave crimes. Officers of a pre-trial investigation institution conducting actions without disclosing their identity shall be prohibited from inciting or inducing a person to commit a criminal act (The Supreme Court 2010b), nor may they resort to procedural coercive measures in relation to which a separate decision or a ruling has not been made. This measure is performed by an officer of the pre-trial investigation institution. In special cases when there are no other possibilities to detect the persons committing crimes, this measure may be also performed by persons who are not officers of a pre-trial investigation institution. A prosecutor must apply for authorisation of this measure. The pre-trial judge's ruling authorising officers of a pre-trial investigation institution to perform actions without disclosing their identity must be written and reasoned, and must indicate the following: (1) the persons who will perform the undercover actions; (2) the person against whom undercover actions are to be performed; (3) information about the person's criminal act; (4) the authorised actions; (5) the result sought; (6) the duration of the undercover actions. The CCP provides that a pre-trial judge, upon receiving an appropriate application from a prosecutor, may order (acoustic and visual) covert surveillance of a person or a motor vehicle or other object (e.g. houses, flats, administrative premises, etc. (Goda et al. 2011, p. 278). An official who has taken part in secret surveillance may be questioned as a witness. If necessary, the rules of non-disclosure of the identity of a witness (official) may be applied. The ruling of a pre-trial judge or the decision of a prosecutor or a pre-trial investigator for surveillance of a person, a motor vehicle or an object must specify the following: (1) the person, the motor vehicle or the object of the surveillance; (2) the reason for such a measure; (3) the duration of the surveillance. If a video or audio recording or filming is sought (intended) during the surveillance, this must also be provided for in the ruling of the pre-trial judge, or the decision of the prosecutor or the pre-trial investigator. In cases of utmost urgency, all these covert (secret) investigative actions may also be applied by the decision of a prosecutor or a pre-trial investigator; however, if this is the case, the consent of the pre-trial judge must be sought within 3 days of the commencement of these actions. If such consent is not forthcoming, any actions that have been initiated must be terminated and all collected information must be destroyed. A record of actions simulating a criminal act, actions of the officers of a pre-trial investigation institution without disclosing their identity and secret surveillance shall be made and must be added to the case file.

During a pre-trial investigation, a pre-trial investigator and a prosecutor may carry out procedural coercive measures and investigative actions provided in the CCP. The $\mathrm{CCP}$ establishes an exhaustive list of these procedural coercive measures and investigative actions, which means that the pre-trial investigator, prosecutor, pre-trial judge and the court may apply only those actions. This list provides such procedural coercive measures and investigative actions as provisional arrest, committal of the suspect to a medical institution, detention, taking of samples for comparative analysis, search, seizure, temporary limitation of property rights, temporary removal from office, the prosecutor's right to request information, taking photographs, filming, taking measurements, fingerprints and samples for genetic 
dactiloscopy, actions of the officers of a pre-trial investigation institution without disclosing their identity, simulation of a criminal act, covert surveillance, etc.

The CCP provides that the prosecutor who acts as the prosecuting party during the trial must bring a civil action, if it has not yet been brought, where injury to the State has been caused by a criminal act. Furthermore, when a civil action is brought at the pre-trial investigation stage, the pre-trial investigator and prosecutor must collect information proving the legal ground and value of the civil action. During the criminal procedure, a pre-trial investigator, prosecutor or the court must invoke remedies for the pending civil action: to discover property belonging to the suspect or the accused, or a person who bears material responsibility for the actions of the suspect or the accused and to impose a temporary limitation of property rights.

A temporary limitation of the property rights of a suspect or a natural person who is financially responsible for the actions of the suspect, or of another natural person who has possession of property received or acquired by criminal means, may be imposed by the decision of a prosecutor. The temporary limitation of the property rights of a legal entity also may be imposed with a view to securing a civil claim or the confiscation of property. According to scholars of the Lithuanian criminal procedure (Bilius and Stonys 2016, p. 389), a temporary limitation of property rights is a procedural coercion measure, which fulfils a preventive function. A temporary limitation on property rights may be imposed together with or separately from a seizure or search. A temporary limitation of property rights shall be revoked by the decision of a prosecutor or a court ruling where the measure is no longer necessary. A prosecutor's decision on a temporary limitation of property rights may not be for longer than for a period of 6 months. This term may be extended, but for not more than two periods of 3 months by a ruling of a pre-trial judge. However, the number of extensions in cases involving serious and grave crimes or when a suspect is in hiding shall not be subject to any limits. Where a temporary limitation is imposed on bank deposits, all transactions involving them shall be suspended if the decision on a temporary limitation of property rights does not provide otherwise. A person on whom a temporary limitation of rights of property has been imposed shall be entitled to appeal against the decision of the prosecutor to the pre-trial judge. Such an appeal must be reviewed by the pre-trial judge within 3 days from the receipt of the appeal. The decision of the pre-trial judge may be appealed against to a higher court, the decision whereof shall be final and not subject to appeal.

\section{Criminological Data}

\subsection{General Data on Registered Crimes of Illicit Trade in Tobacco Products}

The crime rate during 2005-2016 shows a constantly growing number of registered crimes of illicit trade in tobacco products (smuggling (Art. 199, CC), unlawful 
possession of goods subject to excise duties (Art. $199^{2}, \mathrm{CC}$ ), customs deceit (Art. $199^{1}$, CC) and unlawful failure to bring goods or products outside the Republic of Lithuania (Art. 200, CC)), of cases involving illicit trade in tobacco products decided in court, and of sentenced persons (see Table 1). ${ }^{13}$ It should be noted that this data is of a general nature; illicit trade in tobacco products is not distinguished from illicit trade of other kinds of products. On the other hand, statistical data and scientific research show that, for example, about $80 \%$ of smuggling cases consist of cigarette smuggling (Bikelis et al. 2017, p. 40). Data on the number of registered crimes of illicit trade in tobacco products shows that the largest proportion of these crimes is constitutes by smuggling, the highest number of which was recorded in 2013, at 599. The next most frequently registered crime of this type is unlawful possession of goods subject to excise duties, the highest number of which was reported also in 2013, at 394. Meanwhile, the highest number of other registered crimes of this type, deceit of customs, was registered in 2011 (8 cases), while the highest number of cases (14) of unlawful failure to bring goods or products outside the Republic of Lithuania was registered in 2010. It should be noted that in the opinion of experts (confirmed by trends in illicit trade in tobacco products), tobacco smuggling and other crimes of illicit trade in tobacco products are likely to remain at the same level in the nearest future.

The biggest number of cases decided in court involving smuggling was in 2014, at 220, while cases of unlawful possession of goods subject to excise duties was in 2015, at 230. In addition, the highest number of persons sentenced (acquitted) for smuggling was in 2014-277 (13), and of unlawful possession of goods subject to excise duties was in 2015-328 (10).

Data on the value of seized illegal goods (which is of a general nature; illicit trade in tobacco products is not distinguished from illicit trade of other kinds of products) shows that the highest value of seized goods was in 2014, and amounted to $€ 42.9$ million (see Table 2). ${ }^{14}$ Meanwhile, the largest number of seized cigarettes was in 2016 - 238 million packs — and the highest volume of seized tobacco was in 2011 $69,000 \mathrm{~kg}$.

Moreover, data on losses caused by tobacco products detected during the period of 2010-2018 shows that the greatest damage was caused in 2016-€29.2 million, while the lowest was caused in $2013-€ 10.2$ million $^{15}$ (see Table 3). In Lithuania, 570 million smuggled cigarettes were consumed in 2017. According to the "Project Sun" survey, it is estimated that the country's budget lost $€ 62$ million of potential income due to the shadow tobacco market. Growth of the illicit market for tobacco

\footnotetext{
${ }^{13}$ Data on the number of registered crimes, decided cases in courts and sentenced (acquitted) persons was collected from the databases of the Statistics Department, the National Court Administration and Yearly Reports of the Prosecutor General.

${ }^{14}$ Data on the number of detected administrative offences, initiated pre-trial investigations, value of seized illegal goods, number of seized cigarettes (in packs), number of seized tobacco (in kilos) and number of detected and closed illegal factories for counterfeiting cigarettes was collected from the databases of the Customs Criminal Service.

${ }^{15}$ Data received from the Customs Department.
} 
by $1 \%$ generates about $€ 3$ million in losses for the state budget. According to the Nielsen Empty Packet Survey, illegal cigarettes accounted for $16.5 \%$ of the Lithuanian market in 2018 (for example, in 2017, illegal cigarettes in Lithuania accounted for $19.6 \%$ of the market) (Ignotas 2018).

\subsection{Data on Punishments and Measures (Penal and Others) Applied with Regard to Offenders of Illicit Trade in Tobacco Products}

Lithuanian statistics on imposed punishments and penal measures did not provide separate data on punishments and penal measures for the illicit trade in tobacco products. The number of persons serving imprisonment for smuggling (Art. 199, CC) decreased from 79 in 2012 to 47 in 2017. Moreover, 26 persons were newcomers to prison sentenced for smuggling and 26 persons who had been sentenced for smuggling were released from prison in 2017 (see Table 4). ${ }^{16}$ The average court-imposed term of imprisonment increased from 6 years 2 months and 2 days in 2012 to 6 years 7 months and 16 days in 2016; while the average of actually served terms of imprisonment increased from 2 years 3 months and 5 days in 2012 to 2 years 9 months and 10 days in 2017 (see Table 5). ${ }^{17}$ It should be noted that the average term of imposed and actually served terms of imprisonment for smuggling was significantly longer than the general average, which consisted of 7 years and 10 days and 4 years 3 months and 19 days in 2017 respectively (see Table 5). ${ }^{18}$ Moreover, the average term of actually served imprisonment for smuggling increased significantly from 2 years 2 months and 17 days in 2012 to 4 years 3 months and 19 days in 2017.

Notably, the number of suspected (accused) legal persons was relatively high, and ranged from 110 in 2010 to 29 in 2016. On the other hand, few of them were suspected (accused) of smuggling-only 1 in 2008 and 2010-2012 (see Table 6). ${ }^{19}$

It is worth mentioning the results of a scientific study on cigarette smuggling in Lithuania that was published in 2017 (Bikelis et al. 2017). According to the study, during 2009-2013, about $80 \%$ of all convicts at the time of commission of their

\footnotetext{
${ }^{16}$ Data on newcomers to correctional institutions sentenced for smuggling, persons imprisoned for smuggling and persons released from prison who were sentenced for smuggling was collected from the databases of the Prison Department.

${ }^{17}$ Data on the general average of court-imposed and actually served terms of imprisonment was collected from the databases of the Statistics Department.

${ }^{18}$ Data on the average of court-imposed and actually served terms of imprisonment for smuggling was collected from the databases of the Prison Department.

${ }^{19}$ Data on the number of suspected and sentenced legal persons was collected from the databases of the Statistics Department. It should be noted that this data is of general nature; illicit trade in tobacco products is not distinguished from other kinds of crimes. Data on the number of legal persons suspected of smuggling was collected from the databases of the Ministry of the Interior.
} 
crimes did not have a criminal record (previous conviction) (Bikelis et al. 2017, p. 68; see Table 7). It should be noted that $57.6 \%$ of persons convicted for smuggling and unlawful possession of goods (cigarettes) subject to excise duties remanded for imprisonment had a criminal record (previous conviction), and only $8.7 \%$ convicted and ordered to pay a fine had a criminal record (previous conviction) (Bikelis et al. 2017, p. 68).

During 2009-2013, imprisonment for smuggling (Para 1, Art. 199, CC) was imposed on 80 persons: up to 6 months -17 , from 6 to 12 months -13 , from 12 to 18 months -7 , from 18 to 24 months -12 , from 24 to 30 months -12 , from 30 to 36 months - 9 and more than 36 months - 10. Meanwhile, a fine for smuggling (Para 1, Art. 199, CC) during 2009-2010 was imposed on 97 persons, and in 2012on 105.

During 2009-2013, imprisonment for unlawful possession of goods (cigarettes) subject to excise duties (Art. $199^{2}$, CC) was imposed on 56 persons: up to 6 months - 7, from 6 to 12 months - 13, from 12 to 18 months-9, from 18 to 24 months -12 and more than 24 months - 15. Meanwhile, a fine for unlawful possession of goods (cigarettes) subject to excise duties (Art. 199 ${ }^{2}, \mathrm{CC}$ ) during 2009-2010 was imposed on 161 persons, and 2012-2013-279.

Moreover, imprisonment was imposed in most cases for persons who committed crimes in complicity- $15.5 \%$ in cases of a group of accomplices and $18.1 \%$ in cases of an organised group (on the distribution of persons sentenced to imprisonment or a fine according to the form of complicity (2009-2013) see Table 8).

Also, it should be noted that young people under 25 years of age dominate among those sentenced to imprisonment for smuggling, and persons under 34 years of age constitute over $90 \%$ (Bikelis et al. 2017, p. 71). Meanwhile, among those sentenced to imprisonment for unlawful possession of goods (cigarettes) subject to excise duties acts and smuggling (so-called "truck drivers" cases), prisoners under the age of 25 did not appear at all (on the distribution of persons sentenced to imprisonment by age and by crime qualification (in per cent) (2009-2013) see Table 9).

Official data on estimated the financial impact of prosecuted cases of illicit trade in tobacco products and the total amount and share of asset recovery related to illicit trade in tobacco products is not collected in Lithuania.

\subsection{Short Description of the Most Interesting and/or Exemplary Case Studies with Regard to Illicit Trade in Tobacco Products}

One of the biggest smuggling case in Lithuania was the case in which M.T. and 32 other people were accused of more than 150 crimes committed in a criminal association. For example, this criminal association was accused on cigarette smuggling, when in Lithuania alone 19 trucks with smuggled cigarettes from Russia and Belarus were seized with a value of approx. 23 million litas. Another 12 cargoes 
(value of approx. 10 million litas) were detained in Latvia, Estonia, Poland and Germany. The criminal association operated until 2011 in Lithuania, Latvia, Belarus, Russia, the Netherlands and Germany. According to prosecutors, from the beginning of 2008 until the end of 2011, members of the association bought several cargo haulage companies, several dozen trucks and semi-trailers with cigarette shelters. Cigarettes were purchased from special criminal funds in Russia and Belarus. Smuggling of cigarettes was organised by the continual use of transportation schemes and other means of transportation, routes and hiding places, falsified car indentification numbers; some cigarettes were transported by using timber cargo mulches; semi-trailers and their registration numbers were changed at intermediate locations of cigarette transportation; in some cases, unhindered transportation of cigarettes through the Lithuanian state border was secured by bribed customs officials, etc. Prosecutors also brought charges claiming that members of the association in Lithuania produced at least $1200 \mathrm{~kg}$ of first-class precursors of narcotic and psychotropic substances, which they sold to other persons for at least $€ 1.5$ million (Sinkevičius 2015).

Another large-scale smuggling case investigated in Lithuania, in which former police officer V. K. was accused with other persons of having formed a criminal association and having organized a cigarette smuggling ring valued at millions of euros in Russia, Belarus, Poland and Germany. The prosecutor claimed that cigarettes were brought to Lithuania from Belarus in 2009-2010 and transported from Lithuania to Germany via Poland. In addition, the prosecutor's accusation states that smugglers gave bribes worth approx. $€ 50,000-80,000$ to customs officials (Steniulienè 2019).

Main types of smuggling in Lithuania:

- carriage of tobacco products which are hidden among other goods in trucks;

- carriage of tobacco products which are indicated in documents as other goods in trucks;

- "open" carriage of tobacco products in small transport vehicles (e.g. Ford Transit, Fiat Ducato, Volkswagen Transit, etc.) with the expectation that customs officials will not carry out an inspection (as a rule, on the border between Lithuania and Latvia);

- waterway transport of tobacco products over the Nemunas River by so-called ichtiandrs, sometimes even underwater transhipment (as a rule, on the border between Lithuania and Russia (Kaliningrad);

- first attempts for the carriage of tobacco products by railway transport were detected in 2018;

- physical carriage by natural persons of tobacco products through the state border (usually in the forest between Lithuania and Belarus).

Also, there are other qualitative differences between the small and large-scale illegal trade in cigarettes. Small-scale consumers are residents of Lithuania, while large-scale illegal trade in cigarettes usually is dedicated to transit from cheap illegal (or legal) cigarette factories in Belarus and Russia to Western European countries (Germany, United Kingdom, Ireland, Sweden, Norway, etc.), which, due to 
economic and geographic peculiarities, form a "trade belt" of networks dealing in illegal trade in cigarettes (Bikelis et al. 2017, p. 55).

\subsection{Characteristics of Perpetrators of Illicit Trade in Tobacco Products in Lithuania (Age, Gender, Education, Nationality/Citizenship, Prior Criminal Record, Other Information)}

The results of the above-mentioned study on cigarette smuggling in Lithuania show that during 2009-2013, in the case of administrative offenses, a significant proportion of the offenders (especially in the case of illegal possession of cigarettes) consisted of women, whereas criminal cases of smuggling were dominated by men (Para 1, Art. 199, CC), as was unlawful possession of goods subject to excise duties (Art. $199^{2}, \mathrm{CC}$ ). Out of 1165 persons prosecuted under the above-mentioned articles of the CC, men accounted for as much as $97.4 \%$ (1135), while only $2.6 \%$ (30) were women (Bikelis et al. 2017, p. 59).

The dominance of men can be explained by the specificity of these crimes. First of all, such crimes often require male physical strength since cigarettes, which must be in large amounts, should be loaded, reloaded, transported, etc. Moreover, such dominance is also explained by men's skills and knowledge about the transport and technical means necessary to commit these criminal acts. Analysis of the age distribution of men convicted for smuggling shows that more than half $(57.2 \%)$ were particularly young ( $\leq 24$ years of age). Meanwhile, slightly older men (35-44 years of age) were mostly (33.1\%) convicted for the unlawful possession of goods subject to excise duties. Men of this age group also constituted the largest share $(38.8 \%)$ among convicts under both articles of the CC (Bikelis et al. 2017, p. 59).

The age of convicted persons is also determined by the fact that persons convicted of smuggling were usually unmarried (68\%). At that time, the proportion of those who had already been convicted of unlawful possession of goods (cigarettes) subject to excise duties was equal ( $42 \%$ and $41 \%$ respectively) (see Table 10 ). It should be noted that the data on the distribution of age and marital status reflect the general family situation in society, i.e. the largest number unmarried convicts are under 24 years of age, from 25 to 44 years old, divorced and widowed from 44 years of age (Bikelis et al. 2017, p. 60).

The analysis of the education of convicts shows that persons convicted under Art. $199^{2}$ of CC and under both articles of CC (53.2\% and $67.3 \%$ respectively) had at least secondary education. Meanwhile, even $47.6 \%$ of convicted persons for the smuggling (Para 1, Art. 199, CC) had not yet been acquired the secondary education (see Table 11). This tendency can also be determined by the young age of convicts for smuggling (Bikelis et al. 2017, p. 61).

The data shows that, at the time of commission of the crime, there were more unemployed than those in work among persons convicted for a single crime (see 
Table 12). In contrast, when a person was convicted of both crimes (Para 1, Art. 199 and Art. $199^{2}$, CC), the number of employed was, on the contrary, higher than that of unemployed. It is likely that this group of convicts consisted mostly of truck drivers trying to make a profit from illegal activity-smuggling of cigarettes and their further transport in the territory of Lithuania (when a truck is detained at a border customs post, the driver's activity is usually qualified as concurrence of two crimes (Art. 199 and $199^{2}$, CC) (Bikelis et al. 2017, pp. 62-63).

The distribution of convicts by citizenship shows that the vast majority of persons convicted only under one of the articles (Art. 199 or Art. $199^{2}$, CC) were citizens of Lithuania. Among the persons convicted under both articles of $\mathrm{CC}$, citizenship varied, as there were more frequent cases committed not only by citizens of Lithuania, but also of neighbouring countries (citizens of Belarus, Poland and Russia) (see Table 13). Most of them were truck drivers detained crossing the Lithuania state border with hidden cigarettes (Bikelis et al. 2017, p. 63).

Official data from the databases of the Ministry of the Interior on the distribution of those suspected of smuggling (Art. 199, CC) by gender, education (see Table 14), occupation (see Table 15) and citizenship (see Table 16) does not show a greater difference in the period of 2014-2018.

It should be noted that crimes involving illicit trade in tobacco products are most commonly committed in complicity through the forms of a group of accomplices and organized group (and only in some instances - criminal association, which is the most dangerous form of organised crime). Usually, smuggling (Art. 199, CC) is committed by a group of accomplices or by an organized group (see Table 17). Meanwhile, unlawful possession of goods (cigarettes) subject to excise duties (Art. $199^{2}$, CC) or both crimes are usually committed by a single truck driver. If the cargo is seized at a border crossing point during routine customs checks (without criminal intelligence), it is very difficult to the establish driver's relationship with the organizers and other accomplices. The driver does not usually provide the identities of accomplices, assumes the guilt and presents unconvincing stories that he/she is the organizer and perpetrator of the crime. It should be noted that data on complicity was not even obtained; the circumstances of many cases indirectly indicated that the driver was not alone (for example, a large quantity of cigarettes and bad financial situation of the driver may give rise to doubts as to his/her ability and possibility to obtain a large quantity of cigarettes, as well as to transport them independently, etc.). If detection is the result of a criminal intelligence investigation, the cigarette transport scheme and accomplices are more often identified (Bikelis et al. 2017, p. 58).

According to the data, the organizers were mostly 25-34 years old (50\% of all convicts). Persons aged less than 25 years old and over 44 years old people among the organizers constituted only 22\%. Married persons accounted for 52\% of the organizers, while two-thirds of them were officially employed. Higher education was held by 24 , while $56.5 \%$ had a secondary education. A total of $24 \%$ of organizers had a criminal record. Although the social portrait of these individuals was quite positive, in smuggling cases, as many as $38 \%$ (unlawful possession of goods (cigarettes) - 
$15 \%$ ) of organizers were sentenced to real imprisonment (Bikelis et al. 2017, pp. 64-65).

Meanwhile, convicted accomplices make up a vast majority of the perpetrators$84.3 \%$. Two groups of perpetrators can be distinguished - the so-called "mules" carrying cigarettes on their person (in $90 \%$ of all cases - through a "green zone") and drivers. The "mules" constituted $58 \%$ of all perpetrators. According to the data, "mules" were mostly young men: under 25 years old- $63 \%$, younger than 34 years old $-82 \%$. Only $13 \%$ of them were married; $25 \%$ were officially employed; $11 \%$ had completed tertiary education (57\% did not even have secondary education). Of the "mules", $24 \%$ had a criminal record, while $27 \%$ of them had been imprisoned (Bikelis et al. 2017, p. 66). The social portrait of the second group, drivers (not truck drivers), exhibits many similarities to the "mules", but was a little "brighter". Drivers are somewhat older, although a large proportion of them $(50 \%)$ consisted of young people under 25 years of age; $43 \%$ were married; $43 \%$ were officially employed; $8 \%$ had completed higher education (51.4\% — did not have secondary education). A criminal record was found for $22 \%$ of drivers. Only $19.5 \%$ of drivers had been sentenced to real imprisonment (Bikelis et al. 2017, p. 66).

Another group of perpetrators consists of truck drivers carrying illegal (usually hidden) cigarette loads through customs posts. This group of perpetrators dominates among those convicted under both articles (Para 1, Art. 199 and Art. 199 ${ }^{2}$, CC). The age of these convicts is older: the predominant age groups were $35-44$ years $(43 \%)$ and 25-34 years (33\%). A large majority of them were officially employed; two-thirds were married. There was no criminal record for $97 \%$ of them. Of these persons, $71 \%$ were convicted of the carriage of cigarette loads of a very high value. Most of them were citizens of foreign countries (Russia, Belarus) (Bikelis et al. 2017, pp. 66-67).

Moreover, accessories are usually members of lower social class and are local residents of border villages. In smuggling cases, $71 \%$ of them were under 24 years of age. These statistics do not include children, who are sometimes involved in cigarette smuggling. Other social data was "poor"-only $27 \%$ were officially employed; $11 \%$-married; $40 \%$-without secondary education. Of the accessories in smuggling cases, $20 \%$ had a criminal record. Despite their relatively small role, $13 \%$ of accessories were sentenced to real imprisonment (Bikelis et al. 2017, p. 68).

\section{Preventive Measures}

Lithuania has implemented certain measures in compliance with FCTC and the Protocol, as well as the Tobacco Directive (Directive 2014/40/EU of the European Parliament and of the Council), which are covered by the above-mentioned Law of Control of Tobacco, Tobacco Products and Related Products: 


\subsection{Measures Relating to Track and Tracing System}

Requirements for a "track and tracing" system were added to the Law on Control of Tobacco, Tobacco Products and Related Products on 9 June 2016 by amending law No. XII-2419 (The Parliament of the Republic of Lithuania 2016a). These requirements came into force on 20 May 2019. In accordance with the above-mentioned Law, on 16 November 2018, the head of the State Tax Inspectorate under the Ministry of Finance adopted Order No. VA-90 "On the Establishment of a Procedure for Marking and Registration of Wholesale Tobacco Packaging as referred to in Article 14(1) of the Law on Control of Tobacco, Tobacco Products and Related Products" (State Tax Inspectorate under the Ministry of Finance of the Republic of Lithuania 2018), which states that the wholesale packaging of tobacco products shall be marked and registered in accordance with the procedure laid down in the European Commission (hereinafter-EC) Implementing Regulation (EU) 2018/ 574 of 15 December 2017 technical standards for the establishment and operation of the traceability system for tobacco products (The European Commission 2017). Thus, the Lithuanian system of national regulation on the "track and tracing" system of tobacco products is fully compliant with EC standards as well as the requirements of the Protocol.

\subsection{Measures Relating to the Reduction of Demand for Tobacco}

Price and tax measures were taken to reduce the demand for tobacco products (as in Art. 6, FCTC)_during the last few years prices of all tobacco products have increased; in only the last year the price of electronic cigarettes liquid fillings increased twice due to new excise duty rates which had not been previously applied to electronic cigarettes; the rates of excise duties have increased again since March 2019, raising tobacco product prices even higher.

Non-price measures to reduce the demand for tobacco products (as in Art. 7, FCTC) include education on the effects of short and long-term passive and active smoking on one's health in schools, medical institutions, etc. Other measures include various legal restrictions: it is forbidden to sell tobacco products in vending machines, in pharmaceutical companies, health care, education, cultural institutions, Internet cafes (online clubs, etc.); locations for sale of tobacco products are restricted to specialised kiosks - it is forbidden to place and sell any tobacco products at checkouts or anywhere in stores next to other products. It is also forbidden to give away free samples of tobacco products, include them in sets with other products, add them as a present or a prize in lotteries or games, exchange them for coupons, etc., affect buyers by showing discounts for tobacco products, sell any other products whose design imitates tobacco products or marking them with their signs. 
Protection from exposure to tobacco smoke (as in Art. 8, FCTC). It is forbidden to smoke inside cafés and, currently, even though smoking is not strictly forbidden in the outdoor areas of cafés, café managers must ensure that customers are not forced to breathe in tobacco smoke. A new legislative amendment has been registered which aims to completely ban smoking in outdoor cafés as well as on balconies and terraces of apartment buildings if at least one resident of the building is opposed to smoking, as well as at public transport stops (pavilions), playgrounds and leisure venues where sporting events or other events take place.

Regulation of the contents of tobacco products (as in Art. 9, FCTC and Art. 3, Tobacco Directive) include standards for maximum amount of released substances: $10 \mathrm{mg}$ of resins, $1 \mathrm{mg}$ of nicotine, $10 \mathrm{mg}$ of $\mathrm{CO}$ (carbon monoxide) per cigarette. In order to reduce the addictiveness of the product, it is forbidden to place tobacco products on the market which have, for example, added flavours or smells which would hide the natural taste, smell, strength of tobacco, as well as any vitamins, caffeine, taurine or other components associated with energy, healthy lifestyle (or give the impression that particular cigarettes are somehow less detrimental to health). Also, there cannot be any tobacco, nicotine, or flavouring in cigarette filters, paper, capsules or any other technical element of a cigarette. It is prohibited to sell oral, chewing and snuff tobacco in Lithuania.

Regulation of tobacco product disclosures (as in Art. 10, FCTC)—manufacturers and/or importers of tobacco products have to submit a specified form of report to the Drug, Tobacco and Alcohol Control Department that includes a list of components, their quantity and other features of all tobacco products in accordance with legal regulations as well as sales volumes of each product. The gathered information is publicly accessible online.

Packaging and labelling of tobacco products is specific (as in Art. 11, FCTC and section II, Tobacco Directive): every package of cigarettes must be marked with certain warning signs which inform users about the health risks of the product - texts about the health risks of smoking or pictures showing diseases caused by smokingthat must fill at least $50 \%$ of the package surface (if composed of combined text and picture-65\%, other tobacco products—at least $30 \%$ ), they cannot be covered in any way (with extra packaging, stickers, prices, etc.) and must be in Lithuanian. It is also forbidden to include any elements on the package which make a false impression that the product is somehow less harmful to one's health (statements, markings, etc.). The package must include a unique identifier allowing to determine the production date, place, transfer routes, etc. as well as to carry a tamper-proof security feature composed of visible and invisible elements.

Education, communication, training and public awareness (as in Art. 12, FCTC)—schools that deliver formal education incorporate issues about the health damage caused by the use of tobacco products, a health-friendly environment preventing damage from smoking, and a healthy lifestyle into the general education curriculum. Information and a list of ingredients of each tobacco product containing tar, nicotine and carbon monoxide are available and distributed to consumers by all appropriate means. 
Tobacco advertising and promotion in mass media (open or hidden) is forbidden, as well as sponsorship (as in Art. 13, FCTC). At retail outlets, only certain formal and brief information on equipment intended to accommodate tobacco products is allowed.

Demand reduction measures concerning tobacco dependence and cessation (as in Art. 14, FCTC): smoking is prohibited in all educational, social service institutions providing social care and/or social care services for children, health care institutions and their premises; workplaces in enclosed spaces (except special facilities (places) where smoking is allowed if they comply with requirements), in common dwellings, other common areas where non-smokers may be forced to breathe in smoke-polluted air; all types of public transport, except long-distance trains, which must include separate wagons for non-smokers and smokers, as well as aircraft with separate seats for non-smokers and smokers; restaurants, cafes, bars, other catering establishments, clubs, discos, Internet cafes (internet clubs, etc.), gambling houses (casinos), vending machines or bingo halls, other leisure facilities, sports facilities or other events, and other facilities for serving people, except specially equipped cigar and/or pipe clubs. Municipal councils have the right to prohibit smoking in public places (parks, squares, etc.) and other areas within their competence. Management bodies of a legal person must ensure that employees of legal persons, serviced customers and visitors are not forced to breathe in air contaminated with tobacco smoke, and that special warning rooms (places) and smoking rooms are provided in visible places with placards or signs pointing to them.

\subsection{Measures Relating to the Reduction of the Supply of Tobacco}

Illicit trade in tobacco products (as in Art. 15, FCTC) is controlled by preventive, administrative and criminal legal measures. The main national institutions responsible for the prevention of illicit trade in tobacco products are, inter alia, the Customs Department and Drug, Tobacco and Alcohol Control Department. The Customs Department carries out risk assessment using all available information sources; creates risk profiles, which automatically notify customs officers about risks occurring at the borders; performs its own risk profiling at central and regional levels, etc. The Drug, Tobacco and Alcohol Control Department (established in 2011) participates in forming and implementing state policy on drug, tobacco and alcohol control and use prevention; cooperates with the European Monitoring Centre for Drugs and Drug Addiction and other EU institutions, international partners and with non-EU countries, etc.

Sales to and by minors (as in Art. 16, FCTC) - it is forbidden to sell any tobacco or tobacco-related products (including electronic cigarettes and refill containers) to anyone under 18 years old. It is prohibited for persons under 18 years of to smoke or consume tobacco products age. Tobacco products cannot be sold in any places where 
at least $50 \%$ of products are intended for children. Every point of sale for tobacco products must display warning signs that tobacco products are not sold to anyone under 18. If a person looks young, the cashier has to ask for a document to check the buyer's age. It is prohibited to create and publish commercials in which tobacco products are promoted by underage persons.

It should be noted that there are no official statistics on the impact of the abovementioned measures on illicit trade in tobacco products in Lithuania. Meanwhile, the latest Nielsen Empty Packet Survey (2018) shows that illegal cigarettes still make up $16.5 \%$ of the Lithuanian market (in 2017 this was $19.6 \%$ of the Lithuanian market). Moreover, some experts have emphasised that increasing excise duties on cigarettes may have the same impact as increased excise duties on alcohol: a significant increase of excise duties resulted in a significant increase in alcohol smuggling in 2018. However, not all scientific research shows that increased excise duties on cigarettes have an unambiguous and clear influence on the growth of smuggling (Misiūnas and Rimkus 2007, pp. 45, 47; Bikelis et al. 2017, pp. $12-15$, etc.).

\section{Cooperation}

Laws on national institutions responsible for the fight against illicit trade in tobacco products (CCS, SBPS, Police Department, etc.) provide that these institutions have the right to cooperate with other national and foreign institutions. There is a different legal framework for state authorities to provide information on cooperation by other national institutions. For example, Art. 11 of the Law on Customs (The Parliament of the Republic of Lithuania 2004a) provides that "the Customs, having information about suspected violations of legal acts, the prevention or investigation of which belongs to other law enforcement institutions of Lithuania, shall immediately submit it to these law enforcement authorities within its competence". Meanwhile, the Law on State Border Protection (The Parliament of the Republic of Lithuania 2017) provides the general right for the SBPS to provide gathered information to other state institutions. Only Art. 23 of the above-mentioned Law sets out special obligation for the SBPS to inform customs immediately about illegal transport of goods and cargo not passing through border control points. It should be noted that in order to make cooperation among different state institutions more effective at central and operational levels, the Interagency Cooperation Agreement between Police, Customs and State Border Guard Service (20 May 2002) was signed. Pursuant to the provisions of this agreement, working groups are formed and contact persons appointed at central, regional and local levels of the police, customs and SBPS, cooperation forms are established, forms of sharing criminal intelligence and other data from institutional databases have been defined, etc. Moreover, such bilateral and multilateral national cooperation agreements concluded by the Customs 
Department as the Agreement between the Criminal Intelligence Institutions, the Prosecutor General's Office of the Republic of Lithuania and the District Courts on sanctioning of means of criminal intelligence in the criminal intelligence telecommunications network (2018), Agreement between the Criminal Intelligence Institutions and the Prosecutor General's Office on Co-operation and Coordination of Criminal Intelligence (2017), Cooperation agreement between the Customs Department, State Border Protection Service, Financial Crime Investigation Service and Police Department (2010), Cooperation agreement between the Customs Department and Police Department (2005), etc could be mentioned. In addition, it should be noted that criminal intelligence activities and institutional cooperation on investigation of crimes of illicit trade in tobacco products, in accordance with the Law on Criminal Intelligence, must be coordinated and ensured by the prosecutor.

Assessment of the legal regulation and the opinions of experts allow for the conclusion that the legal framework for interinstitutional cooperation and the division of competences are appropriate and accurate, while practical cooperation and exchange of criminal intelligence (though improved over the past 5-8 years) could be more effective. Nevertheless, experts have pointed out that the main difficulty (or even challenge) is mutual trust, which determines effective day-to-day cooperation (especially exchange of information of criminal intelligence) between different institutions.

Cooperation of the Customs Department and CCS in administrative matters with institutions of other EU Member States is based on the Convention on mutual assistance and cooperation between customs administrations (1998), drawn up on the basis of Article K.3 of the Treaty on European Union. Moreover, the Customs Department has concluded bilateral cooperation treaties with the competent institutions of other EU Member States, for example, the Consortium agreement between the Customs Department of Lithuania and National Board of Customs of Finland (2011), the Agreement between the Customs Department under the Ministry of Finance of Lithuania, the Estonian Tax and Customs Service, the State Tax Service of Latvia and the National Tax Administration of Poland on the exchange of information between automated identification systems (2017), etc. Mutual assistance in criminal matters is carried out by competent prosecutors on the basis of the Convention on Mutual Assistance in Criminal Matters between the Member States of the EU (2000), established by the Council in accordance with Article 34 of the Treaty on European Union, and other EU legal acts on legal cooperation (for example, European Investigation Order according to the Directive for a European Investigation Order, etc.), etc.

The assessment of legal regulation, practice of cooperation and opinions of experts allow for the statement that cooperation on all administrative matters mostly takes place with Latvia, Estonia, Germany, Poland, the United Kingdom and the Scandinavian countries, and it is sufficiently effective. Particular emphasis is placed on the effectiveness of cooperation with Germany and the United Kingdom through liaison officers. Moreover, a few negative aspects of cooperation in criminal matters 
were highlighted: (a) quite significant differences in national legal regulation, particularly of the means and grounds of criminal intelligence, and (b) quite significant differences of state institutions responsible for the fight against illicit trade in tobacco products (for example, some of them are law enforcement agencies and have the right to collect criminal intelligence, while others do not, etc.).

Customs Department and CCS cooperation in administrative matters with the institutions of non-EU Member States (Russia, Belarus, Ukraine, Georgia, USA, etc.) is based on mutual agreements, for example, the Joint declaration between the Customs Department of Lithuania and US Justice department (2010), etc. Mutual assistance in criminal matters is carried out through competent prosecutors only on the basis of the conventions of the Council of Europe (for example, Convention on Extradition and its additional protocols, Convention on Mutual Assistance in Criminal Matters and its additional protocols, etc.), as well as mutual treaties on legal assistance in Lithuanian criminal matters (for example, Lithuania has concluded such treaties with Russia, Belarus, Ukraine, China, USA, etc.). Experts drew attention only to the complicated cooperation with Russia, because the execution of requests takes a long time and quality is poor. This situation may be explained, inter alia, by the fact that Russia (and Belarus, Ukraina, Moldova, etc.) receives substantial income to the state budget from factories producing cheap legal cigarettes, so these countries are not too interested in controlling and cooperating (especially regarding exchange of information) in matters concerning trade in tobacco products.

Furthermore, Lithuanian Customs officers participate in the activities of the Operating Committee of the Task-Force of the Baltic Sea Region on fighting organized crime (Denmark, Estonia, Finland, Germany, Iceland, Latvia, Lithuania, Norway, Poland, Russia and Sweden). The Operating Committee is tasked with facilitating cooperation and promoting the exchange of information on joint operational measures and actions between member states.

Representatives of Lithuanian Customs take part in the activities of the EU Council's working groups, the High Level Working Party of Directors General and expert working groups on Customs Union and Customs Cooperation, as well as in the EU Council's Internal Security Committee (COSI). Experts from Lithuanian Customs participate in the activities of the EC's Committees and Expert Groups. It should be noted that Lithuanian Customs, according to Council Regulation (EC) No 515/97, exchange information with the competent authorities by means of the Anti-Fraud Information System (AFIS), personal data contained in the Export Control System (ECS) and New Computerized Transit Information System (NCTS) with a view to identifying fraud cases. Lithuanian Customs also take part, through competent prosecutors or other officials, in cooperation with special agencies of the EU-EUROPOL, EUROJUST, OLAF. 


\section{General Issues}

\subsection{Rates of Excise Duties on Cigarettes, Cigars, Cigarillos and Smoking Tobacco}

According to the Law on Excise Duties (The Parliament of the Republic of Lithuania 2018), the rates of excise duties on cigarettes, cigars, cigarillos and smoking tobacco from 1 March 2019 in Lithuania are: (a) for cigarettes-€62.25 per 1000 cigarettes (€65.7 from 1 March 2020 and €69.4 from 1 March 2021); (b) a combined excise duty for cigarettes — of at least $€ 102$ per 1000 cigarettes ( $€ 108.5$ from 1 March 2020 and $€ 115.5$ from 1 March 2021); (c) for cigars and cigarillos—€42 per kilogram of product (€48 from 1 March 2020 and $€ 55$ from 1 March 2021); (d) smoking tobacco- $€ 68.6$ per kilogram of product ( $€ 78.5$ from 1 March 2020 and $€ 90$ from 1 March 2021). Meanwhile, in retail stores the official price of the most popular cigarettes "Marlboro" ranges from $€ 3.65$ to $€ 3.87$ per pack.

By comparison, currently, one pack of the most popular smuggled cigarettes from Belarus, "Minsk", "Fest" and "NZ" on the black market in Lithuania costs around €2 (buying up to 10 packs the price is around €2.20/€2.30 per pack, and in larger quantities (for example, more than 1000 packs) - the price of one pack should be around $€ 1.70 / € 1.80$ per pack).

\subsection{Main Social, Political and Geographical Factors Which Contribute to the Illicit Trade in Tobacco Products in Lithuania}

Scientific research, statistical data and the opinions of experts show that the low incomes of residents of some border regions in Lithuania, high differences of prices of tobacco products when comparing Lithuania with neighbouring countries (for example, one pack of cigarettes is 7 times more expensive in Lithuania than in Belarus), and traditional close social contacts (or even family relations) with Belarus are the main social factors which contribute to the illicit trade in tobacco products in Lithuania. Scientific research and statistical data also show a correlation between unemployment and decrease in the consumption of legal cigarettes which was observed in 2008-2010, when rising unemployment significantly reduced consumption of legal cigarettes (Bikelis et al. 2017, p. 18). Furthermore, sociological surveys also show that one of the social factors is the favorable attitude of Lithuanians towards smuggling and the use of smuggled cigarettes (31\% of Lithuanian residents have justified smuggling and illegal use of goods in 2017). Another interesting trend is that the smuggling of tobacco products has been targeted at emigrants from 
Lithuania and other states of the former Soviet Union living in Germany, Norway, Sweden, etc. Also, criminal groups which organize smuggling of tobacco products mostly consist of members from Lithuania or the former Soviet Union. Some experts also have pointed to increased rates of excise duties on cigarettes (even beyond EU requirements), but this factor should be analysed more deeply.

Scientific research (Šatienė et al. 2011, pp. 19-28) and the opinions of experts indicate that among the main political and institutional factors which contribute to the illicit trade in tobacco products in Lithuania are corruption (of customs officials), an insufficient number of officials with the necessary qualifications and practical experience, and the lack of a sufficient number of appropriate technical means (for example, X-ray machines, drones, border protection technologies, etc.). Some experts have pointed out that for a more effective fight against the illicit trade in tobacco products, the following would be beneficial: (i) increase in the number of qualified officials; (ii) increased funding for salaries and (iii) additional technical equipment and modern border surveillance technologies, etc. Moreover, some new investigative rights of CCS (such as the right to receive information constituting a commercial secret from commercial contracts between economic entities) should be considered.

In the opinion of experts, the long border and convenient location as a transit country are the main geographical factors which contribute to the illicit trade in tobacco products in Lithuania. Lithuania shares borders with Latvia (land border$588 \mathrm{~km}$, sea border-22 km), Belarus (border-677 km), Poland (border-104 km) and Russia (Kaliningrad) (land border-255 km, border in Curonian sea- $18 \mathrm{~km}$, sea border-22 km). The EU external border section in Lithuania accounts for $61 \%$ of the total length of the state border (Kazakevičius 2018).

Scientific research (Bikelis et al. 2017, p. 20) also indicates among geographical factors the fact that the Lithuanian (and EU external) border is very close to cheap (legal) cigarette production factories, which are located also in low-taxing states, such us Belarus and Russia.

\section{Conclusion. Identification of Best Practices at the National Level}

The following items can be attributed to the best practices of Lithuanian institutions:

- sufficiently criminal intelligence effective activity. It may be mentioned that in 2018 , as much as $81 \%$ of all illicit tobacco products were detained by SBPS on the ground of information received through criminal intelligence activity;

- sufficiently effective activity of the analytical unit of the Customs Department, on the basis of which a list of potentially dangerous carriers and other legal entities is 
formed. Carriers and other legal persons included in this list are subject to additional, more frequent or more stringent inspections by officials of the Customs Department;

- cooperation with other countries through liaison officers;

- further installation of a guard fence ( $44.64 \mathrm{~km}$ of which is already installed) in the state border section with Russia. Moreover, the portion of the EU's external border (Lithuania) monitored by modern border surveillance technologies is expected to increase to 53\% by the end of the year 2018 (in 2015 it was 32\%, while in 2016-33\%) (Giriūnaite 2018).

\section{Annex: Tables}

Table 1 Data on number of registered crimes, on number of decided cases in courts and on number of sentenced (acquitted) persons

Number of registered crimes

Number of decided cases in courts

Number of sentenced/acquitted persons

\begin{tabular}{|c|c|c|c|c|c|c|c|c|c|c|c|}
\hline 2005 & 2006 & 2007 & 2008 & 2009 & 2010 & 2011 & 2012 & 2013 & 2014 & 2015 & 2016 \\
\hline \multicolumn{12}{|c|}{ 1. Smuggling (art. 199, CC) } \\
\hline 93 & 79 & 122 & 108 & 138 & 179 & 228 & 314 & 599 & 336 & 306 & 449 \\
\hline 74 & 74 & 90 & 62 & 70 & 93 & 105 & 147 & 166 & 220 & 168 & 142 \\
\hline- & - & - & - & - & - & 130 & $238 / 9$ & $205 / 6$ & $277 / 13$ & $238 / 7$ & $213 / 3$ \\
\hline
\end{tabular}

2. Unlawful possession of goods subject to excise duties (art. 199², CC)

\begin{tabular}{l|l|l|l|l|l|l|l|l|l|l|l}
\hline 54 & 70 & 100 & 69 & 108 & 174 & 161 & 215 & 394 & 273 & 241 & 195 \\
- & 543 & 18 & 46 & 77 & 129 & 164 & 147 & 212 & 224 & 230 & 176 \\
- & - & - & - & - & - & 191 & $264 / 6$ & $275 / 4$ & $299 / 7$ & $328 / 10$ & $269 / 9$ \\
\hline 3. Customs deceit (art. 1991, CC) \\
\hline 3 & 1 & 0 & 1 & 1 & 5 & 8 & 4 & 7 & 6 & 3 & 0 \\
- & 0 & 0 & 2 & 1 & 2 & 4 & 2 & 2 & 3 & 2 & 6 \\
- & 0 & 0 & - & - & - & 1 & 3 & 2 & 4 & 4 & $2 / 1$
\end{tabular}

4. Unlawful failure to bring goods or products outside the Republic of Lithuania (Art. 200, CC)

\begin{tabular}{l|l|l|l|l|l|l|l|l|l|l|l}
\hline 8 & 5 & 1 & 3 & 1 & 14 & 7 & 12 & 2 & 3 & 10 & 3 \\
4 & 7 & 7 & 0 & 3 & 2 & 3 & 1 & 0 & 2 & 1 & 3 \\
- & - & - & 0 & - & - & 0 & 9 & 0 & 1 & $1 / 1$ & 1 \\
\hline
\end{tabular}




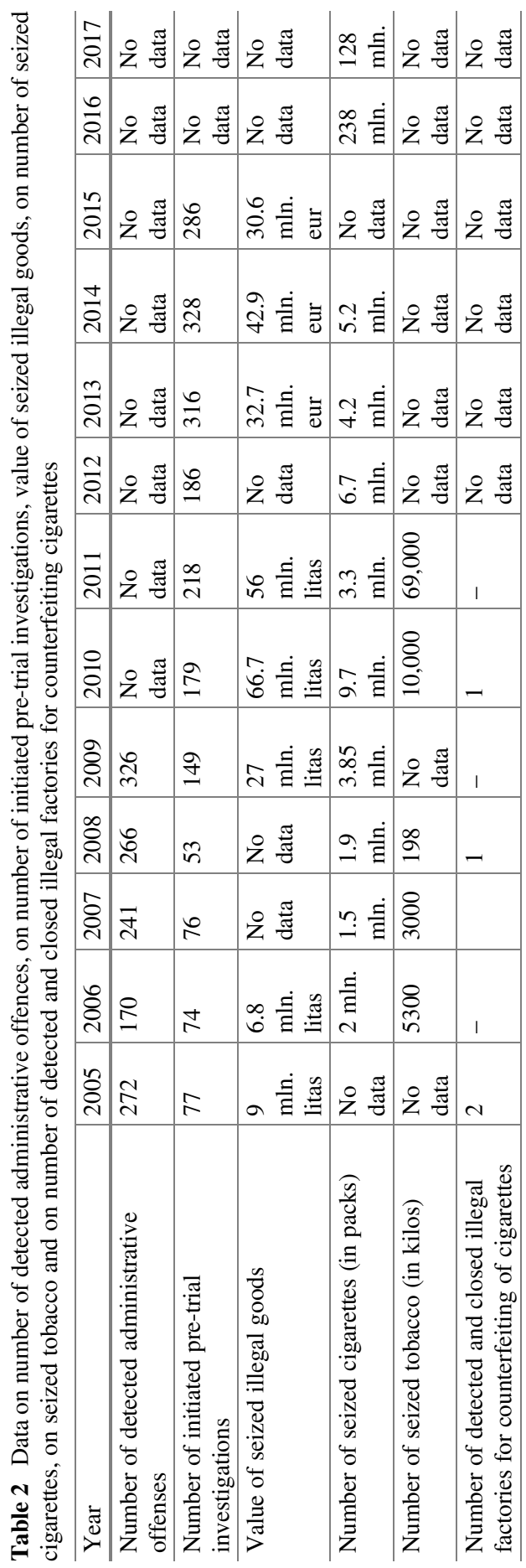


Table 3 Data on damage caused by detected tobacco products

\begin{tabular}{l|l|l|l|l|l|l|l|l|l}
\hline Year & 2010 & 2011 & 2012 & 2013 & 2014 & 2015 & 2016 & 2017 & 2018 \\
\hline $\begin{array}{l}\text { Damage caused by } \\
\text { detected tobacco products } \\
\text { (in millions euros) }\end{array}$ & 15.4 & 12.7 & 11.4 & 10.2 & 12.4 & 24.1 & 29.2 & 15.8 & 20.7 \\
\hline
\end{tabular}

Table 4 Data on newcomers to correctional institutions sentenced for smuggling, imprisoned persons for smuggling and persons released from prison who were sentenced for smuggling

\begin{tabular}{l|l|l|l|l|l|l|l|l}
\hline Year & 2010 & 2011 & 2012 & 2013 & 2014 & 2015 & 2016 & 2017 \\
\hline $\begin{array}{l}\text { Newcomers to prison sentenced } \\
\text { for smuggling (Art. 199, CC) }\end{array}$ & 42 & 24 & 37 & 30 & 27 & 30 & 30 & 26 \\
\hline Persons imprisoned for smuggling & 74 & 75 & 79 & 69 & 54 & 45 & 44 & 47 \\
\hline $\begin{array}{l}\text { Persons released from prison who } \\
\text { were sentenced for smuggling }\end{array}$ & 25 & 20 & 32 & 45 & 45 & 37 & 29 & 26 \\
\hline
\end{tabular}

Table 5 Data on general average of court-imposed and actually served terms of imprisonment

\begin{tabular}{l|l|l|l|l|l|l}
\hline Year & 2012 & 2013 & 2014 & 2015 & 2016 & 2017 \\
\hline Average of court-imposed term of imprisonment & $6 \mathrm{y}$ & $4 \mathrm{y}$ & $6 \mathrm{y}$ & $6 \mathrm{y}$ & $6 \mathrm{y}$ & $7 \mathrm{y}$ \\
for smuggling (Art. 199, CC) & $6 \mathrm{~m}$ & $11 \mathrm{~m}$ & $1 \mathrm{~m}$ & $11 \mathrm{~m}$ & $7 \mathrm{~m}$ & $10 \mathrm{~d}$ \\
& $29 \mathrm{~d}$ & $3 \mathrm{~d}$ & $20 \mathrm{~d}$ & $6 \mathrm{~d}$ & $4 \mathrm{~d}$ & \\
\hline Average of actually served term of imprisonment & $2 \mathrm{y}$ & $2 \mathrm{y}$ & $2 \mathrm{y}$ & $2 \mathrm{y}$ & $3 \mathrm{y}$ & $4 \mathrm{y}$ \\
for smuggling (Art. 199, CC) & $2 \mathrm{~m}$ & $11 \mathrm{~m}$ & $9 \mathrm{~m}$ & $8 \mathrm{~m}$ & $3 \mathrm{~m}$ & $3 \mathrm{~m}$ \\
& $17 \mathrm{~d}$ & $17 \mathrm{~d}$ & $15 \mathrm{~d}$ & $29 \mathrm{~d}$ & $4 \mathrm{~d}$ & $19 \mathrm{~d}$ \\
\hline Average of court-imposed term of imprisonment & $6 \mathrm{y}$ & No & $6 \mathrm{y}$ & $6 \mathrm{y}$ & $6 \mathrm{y}$ & No \\
& $2 \mathrm{~m}$ & data & $3 \mathrm{~m}$ & $5 \mathrm{~m}$ & $7 \mathrm{~m}$ & data \\
& $2 \mathrm{~d}$ & & $12 \mathrm{~d}$ & $28 \mathrm{~d}$ & $16 \mathrm{~d}$ & \\
\hline Average of actually served term of imprisonment & $2 \mathrm{y}$ & $\begin{array}{l}\text { No } \\
\text { data }\end{array}$ & $\begin{array}{l}2 \mathrm{y} \\
7 \mathrm{~m}\end{array}$ & $\begin{array}{l}2 \mathrm{y} \\
8 \mathrm{~m}\end{array}$ & $\begin{array}{l}2 \mathrm{y} \\
9 \mathrm{~m}\end{array}$ & $2 \mathrm{y}$ \\
& $3 \mathrm{~m}$ \\
& $5 \mathrm{~d}$ & & $23 \mathrm{~d}$ & $9 \mathrm{~d}$ & $26 \mathrm{~d}$ & $10 \mathrm{~d}$ \\
\hline
\end{tabular}

Table 6 Data on number of suspected and sentenced legal persons

\begin{tabular}{l|l|l|l|l|l|l|l|l|l|l|l|l}
\hline Year & 2005 & 2006 & 2007 & 2008 & 2009 & 2010 & 2011 & 2012 & 2013 & 2014 & 2015 & 2016 \\
\hline $\begin{array}{l}\text { Number of } \\
\text { suspected } \\
\text { (accused) legal } \\
\text { persons }\end{array}$ & 22 & 47 & 86 & 119 & 112 & 110 & 89 & 47 & 63 & 33 & 35 & 29 \\
\hline $\begin{array}{l}\text { Number of } \\
\text { suspected legal } \\
\text { persons for } \\
\text { smuggling } \\
\text { (Art. 199, CC) }\end{array}$ & 0 & 0 & 0 & 1 & 0 & 0 & 1 & 1 & 1 & 0 & 0 & 0 \\
\hline $\begin{array}{l}\text { Number of } \\
\text { sentenced legal } \\
\text { persons }\end{array}$ & 22 & 18 & 37 & 56 & 67 & 56 & 49 & 33 & - & 30 & 18 & 18 \\
\hline
\end{tabular}


Table 7 Data on convicts who had or did not had previous convictions at the time of crime commission

\begin{tabular}{l|l|l|l}
\hline & $\begin{array}{l}\text { Art. 199, para } \\
1, \text { CC }\end{array}$ & $\begin{array}{l}\text { Art. } 199^{2}, \\
\text { CC }\end{array}$ & $\begin{array}{l}\text { Art. 199, para 1 and Art. } 199^{2}, \\
\text { CC }\end{array}$ \\
\hline Had previous conviction & 21.3 & 15.5 & 3.3 \\
\hline $\begin{array}{l}\text { Did not had previous } \\
\text { conviction }\end{array}$ & 78.7 & 84.5 & 96.7 \\
\hline
\end{tabular}

Table 8 Distribution of persons sentenced to imprisonment or a fine according to form of complicity (2009-2013)

\begin{tabular}{l|l|l|l}
\hline & Single crimes & Group of accomplices & Organised group \\
\hline Imprisonment & 6.8 & 15.3 & 18.1 \\
\hline Fine & 93.2 & 84.7 & 81.9 \\
\hline
\end{tabular}

Table 9 Distribution of persons sentenced to imprisonment by age and by crime qualification

\begin{tabular}{l|l|l|l|l|l}
\hline & $\leq 24$ y/o & $25-34$ y/o & $35-44$ y/o & $45-54$ y/o & $\geq 55$ y/o \\
\hline Art. 199. para 1 & 63.3 & 27.8 & 5.1 & 3.8 & 0.0 \\
\hline Art. 199 & 43.1 & 15.7 & 27.5 & 11.8 & 2.0 \\
\hline Art. 199. para 1 and Art. 199 & 0.0 & 44.4 & 44.4 & 11.1 & 0.0 \\
\hline
\end{tabular}

Table 10 Distribution of convicts by age and marital status

\begin{tabular}{l|l|l|l|l|l}
\hline & Married & Unmarried & Divorced & $\begin{array}{l}\text { Widow/ } \\
\text { widower }\end{array}$ & Unspecified \\
\hline Art. 199, para 1 & $21 \%$ & $68 \%$ & $8 \%$ & $1 \%$ & $1 \%$ \\
\hline Art. 199 & $42 \%$ & $41 \%$ & $13 \%$ & $1 \%$ & $3 \%$ \\
\hline $\begin{array}{l}\text { Art. 199 para 1 and Art. } \\
199^{2}\end{array}$ & $60 \%$ & $26 \%$ & $11 \%$ & $0 \%$ & $3 \%$ \\
\hline
\end{tabular}

Table 11 Distribution of convicts by education

\begin{tabular}{l|l|l|l|l}
\hline & $\begin{array}{l}\text { Without secondary } \\
\text { education }\end{array}$ & $\begin{array}{l}\text { Secondary } \\
\text { education }\end{array}$ & $\begin{array}{l}\text { More than secondary } \\
\text { education }\end{array}$ & Unspecified \\
\hline Art. 199, para 1 & $47.6 \%$ & $41.3 \%$ & $9.8 \%$ & $1.3 \%$ \\
\hline Art. 199 & $22.9 \%$ & $53.2 \%$ & $18.1 \%$ & $5.9 \%$ \\
\hline $\begin{array}{l}\text { Art. 199, para 1 and } \\
\text { Art. 199 }\end{array}$ & $10.0 \%$ & $67.3 \%$ & $16.6 \%$ & $6.2 \%$ \\
\hline
\end{tabular}

Table 12 Distribution of convicts by employment

\begin{tabular}{l|l|l|l|l|l}
\hline & Employed & Unemployed & Studying & Other & Unspecified \\
\hline Art. 199, para 1 & $39.0 \%$ & $46.7 \%$ & $10.8 \%$ & $1.6 \%$ & $1.9 \%$ \\
\hline Art. 199 & $40.4 \%$ & $50.1 \%$ & $3.4 \%$ & $4.6 \%$ & $1.4 \%$ \\
\hline Art. 199, para 1 and Art. 199 & $66.8 \%$ & $29.9 \%$ & $1.9 \%$ & $0.5 \%$ & $0.9 \%$ \\
\hline
\end{tabular}


Table 13 Distribution of convicts by citizenship

\begin{tabular}{l|l|r|r|r|l|l|l}
\hline & Lithuania & Russia & Poland & Belarus & Latvia & Ukraine & Other \\
\hline Art. 199 para 1 & $91.7 \%$ & $5.1 \%$ & $0.3 \%$ & $2.5 \%$ & $0.0 \%$ & $0.0 \%$ & $0.3 \%$ \\
\hline Art. 199 & $93.1 \%$ & $0.2 \%$ & $3.6 \%$ & $1.4 \%$ & $0.3 \%$ & $0.3 \%$ & $0.7 \%$ \\
\hline $\begin{array}{l}\text { Art. 199 para 1 and Art. } \\
199^{2}\end{array}$ & $43.1 \%$ & $14.2 \%$ & $17.1 \%$ & $19.0 \%$ & $2.8 \%$ & $3.3 \%$ & $0.5 \%$ \\
\hline
\end{tabular}

Table 14 Distribution of those suspected of smuggling by gender and education

\begin{tabular}{l|l|l|l|l|l}
\hline Year & 2014 & 2015 & 2016 & 2017 & 2018 \\
\hline Suspected persons for smuggling (Art. 199, CC) & 290 & 222 & 173 & 266 & 188 \\
\hline Men & 277 & 220 & 159 & 254 & 183 \\
\hline Women & 13 & 2 & 14 & 12 & 5 \\
\hline Without secondary education & $18 \%$ & $11 \%$ & $18 \%$ & $21 \%$ & $17 \%$ \\
\hline Secondary education & $60 \%$ & $64 \%$ & $62 \%$ & $56 \%$ & $62 \%$ \\
\hline More than secondary education & $22 \%$ & $25 \%$ & $20 \%$ & $23 \%$ & $21 \%$ \\
\hline
\end{tabular}

Table 15 Distribution of those suspected of smuggling by occupation

\begin{tabular}{l|l|l|l|l|l}
\hline Year & 2014 & 2015 & 2016 & 2017 & 2018 \\
\hline Employed & $59 \%$ & $53 \%$ & $50 \%$ & $49 \%$ & $43 \%$ \\
\hline Unemployed & $33 \%$ & $41 \%$ & $43 \%$ & $36 \%$ & $35 \%$ \\
\hline Studying & $8 \%$ & $6 \%$ & $7 \%$ & $15 \%$ & $22 \%$ \\
\hline
\end{tabular}

Table 16 Distribution of those suspected of smuggling by citizenship

\begin{tabular}{l|l|l|l|l|l}
\hline Year & 2014 & 2015 & 2016 & 2017 & 2018 \\
\hline $\begin{array}{l}\text { Foreigners suspected of smuggling (Art. 199, CC); of } \\
\text { them: }\end{array}$ & 60 & 68 & 56 & 54 & 44 \\
\hline Belarussian & 20 & 28 & 26 & 24 & 12 \\
\hline Russian & 21 & 25 & 13 & 19 & 20 \\
\hline Polish & 9 & 4 & 5 & - & 2 \\
\hline Latvian & - & - & 4 & 4 & 2 \\
\hline
\end{tabular}

Table 17 Distribution of crimes committed as a single crime or in the forms of a group of accomplices and organised group

\begin{tabular}{l|l|l|l}
\hline & Art. 199, para 1 & Art. $199^{2}$ & Art. 199 para 1 and Art. $199^{2}$ \\
\hline Single crimes & 10.8 & 46.8 & 57.3 \\
\hline Group of accomplices & 44.1 & 46.8 & 25.1 \\
\hline Organised group & 45.1 & 6.4 & 17.5 \\
\hline
\end{tabular}




\section{References}

\section{International and European Union Legal Acts, National Laws and Other Legal Acts}

Convention on mutual assistance and cooperation between customs administrations (1998) Convention drawn up on the basis of Article K.3 of the Treaty on European Union. OJ C 24, 23.1.1998, pp. 2-22. Official Gazette Valstybès žinios, 2004, Nos. 67-2355; 112-4180

Convention on Mutual Assistance in Criminal Matters between the Member States of the European Union (2000) Established by the Council in Accordance with Article 34 of the Treaty on European Union. Official Gazette Valstybès žinios, 2004-10-21, No. 154-5599

Directive 2014/40/EU of the European Parliament and of the Council of 3 April 2014 on the approximation of the laws, regulations and administrative provisions of the Member States concerning the manufacture, presentation and sale of tobacco and related products and repealing Directive 2001/37/EC

Prosecutor General (2003a) Recommendation "On the Distribution of the Pre-Trial Investigation Between the Institutions of the Pre-Trial Investigation”. Official Gazette Valstybès žinios, No. 39-1805

Prosecutor General (2003b) Order "On the Compilation of the Recommendation on the Report to be Submitted Upon Completion of a Pre-Trial Investigation (Article 218 of the Code of Criminal Procedure)". Official Gazette Valstybès žinios, No. 39-1805

Prosecutor General (2013) Order “On Approval of the Recommendations on the Law on Criminal Intelligence, Application of the Norms of the Code of Criminal Procedure and Use of Criminal Intelligence Information in Criminal Proceedings”. Official Gazette Valstybès žinios, No. 2-83

Prosecutor General (2015) Order of the Prosecutor General "On the Recommendation on the Compilation and Transmission of an Indictment to a Court". Register of Legal Acts, No. 2015-08536

State Tax Inspectorate under the Ministry of Finance of the Republic of Lithuania (2018) Order "On the Establishment of a Procedure for Marking and Registration of Wholesale Tobacco Packaging as referred to in Article 14(1) of the Law on Control of Tobacco, Tobacco Products and Related Products". Register of Legal Acts, No. 18573

The Council of Europe Criminal Law Convention on Corruption (1999) Strasbourg, 27 January 1999. Official Gazette Valstybés žinios, 2002, No. 23-851; 23-853

The European Commission (2017) The European Commission Implementing Regulation (EU) 2018/574 of 15 December 2017 on technical standards for the establishment and operation of a traceability system for tobacco products

The Government of the Republic of Lithuania (1999) Description of the procedure for destruction of tobacco products confiscated and transferred to the state. Official Gazette Valstybès žinios, No. $85-2537$

The Government of the Republic of Lithuania (2004) Resolution of the Government "Exemption of Goods Imported by Travelers from VAT and Excise Duties on Imports". Official Gazette Valstybés žinios, No. 58-2049

The Government of the Republic of Lithuania (2017) Regarding the Government of the Republic of Lithuania October 14 Resolution no. 1031 "On the Basic Approval of the Amount of Punishment and Penalties". Register of Legal Acts, No. 14215

The Minister of Economy (2004) Order of the Minister of Economy No. 4-200 "On Approval of the Rules for the Transport and Storage of Alcohol Products and Tobacco Products Applicable to Natural Persons in the Territory of the Republic of Lithuania”. Official Gazette Valstybés žinios, Nos. 4-759, 92-4590

The Parliament of the Republic of Lithuania (2000a) The Law on Intelligence. Official Gazette Valstybès žinios, No. 64-1931 
The Parliament of the Republic of Lithuania (2000b) The Criminal Code of the Republic of Lithuania (2000). Official Gazette Valstybès žinios, Nos. 89-2741, 112-4973

The Parliament of the Republic of Lithuania (2002a) Law on Value Added Tax. Official Gazette Valstybès žinios, No. 35-1271

The Parliament of the Republic of Lithuania (2002b) The Code of Criminal Procedure of the Republic of Lithuania. Official Gazette Valstybès žinios, No. 37-1341

The Parliament of the Republic of Lithuania (2003) Law on Control of Tobacco, Tobacco Products and Related Products. Official Gazette Valstybès žinios, No. 117-5317

The Parliament of the Republic of Lithuania (2004a) Law on Customs. Official Gazette Valstybejs žinios, No. 73-2517

The Parliament of the Republic of Lithuania (2004b) The Law on Ratification of the WHO Framework Convention on Tobacco Control No. IX-2460. Official Gazette Valstybès žinios, No. 152-5529

The Parliament of the Republic of Lithuania (2010) Law on Excise Duty. Official Gazette Valstybes žinios, No. 45-2174

The Parliament of the Republic of Lithuania (2012) Criminal Intelligence Act. Official Gazette Valstybès žinios, No. 122-6093

The Parliament of the Republic of Lithuania (2015) Code of Administrative Offenses of the Republic of Lithuania. Register of Legal Acts, No. 2015-11216

The Parliament of the Republic of Lithuania (2016a) Law on Amending the Law on Control of Tobacco, Tobacco Products and Related Products. Register of Legal Acts, No. 2016-17405

The Parliament of the Republic of Lithuania (2016b) Law on the Ratification of the Protocol to Eliminate Illicit Trade in Tobacco Products. Register of Legal Acts, No. 26439

The Parliament of the Republic of Lithuania (2017) Law on State Border Protection. Register of Legal Acts, No. 12168

The Parliament of the Republic of Lithuania (2018) Law amending Article 26 of the Law on Excise Duties No. IX-569. Register of Legal Acts, No. 20967

The Union Customs Code (2013) Regulation (EU) No 952/2013 of the European Parliament and of the Council of 9 October 2013 laying down the Union Customs Code. - OJ L 269, 10.10.2013, pp. $1-101$

\section{Jurisprudence of the Constitutional Court of Lithuania, Supreme Court of Lithuania and Other Courts}

Kaunas Region Administrative Court (2012) Decision of 22 October 2012 in admnistrative case No. Ik-124-505/2012

The Constitutional Court (2001) Ruling of 7 May 2001 "Dèl Lietuvos Respublikos administraciniu teisès pažeidimu kodekso 130(2) straipsnio atitikties Lietuvos Respublikos Konstitucijai". Official Gazette Valstybès žinios, No. 39-1373

The Constitutional Court (2005) Ruling of 10 November 2005 "Dèl Lietuvos Respublikos administracinių teisès pažeidimų kodekso 163(2) atitikties Lietuvos Respublikos Konstitucijai". Official Gazette Valstybès žinios, No. 134-4819

The Constitutional Court (2009) Ruling of 8 June 2009 "Dèl Lietuvos Respublikos baudžiamojo kodekso 20 straipsnio 1, 2, 3 dalių, 20 straipsnio 5 dalies, 43 straipsnio 4 dalies atitikties Lietuvos Respublikos Konstitucijai”. Official Gazette Valstybès žinios, No. 69-2798

The Supreme Administrative Court (2012) Ruling of 25 January 2012 in administrative case No. A143-250/2012

The Supreme Court (2007a) Ruling of 3 April 2007 in criminal case No. 2K-251/2007

The Supreme Court (2007b) Ruling of 13 November 2007 in criminal case No. 2K-P-549/2007

The Supreme Court (2010a) Ruling of 27 April 2010 in criminal case No. 2K-269/2010 
The Supreme Court (2010b) Ruling of 31 May 2010 in criminal case No. 2K-313/2010

The Supreme Court (2016) Ruling of 23 February 2016 in criminal case No. 2K-7-85-696/2016

\section{Special Literature}

Bikelis S, Giedraitytė-Mačiulienė R, Mickènienė I, Venckevičienė J (2017) Cigarečių neteisèta apyvarta: kompleksinè reiškinio ir kontrolès priemoniu analizè. Eugrimas, Vilnius

Bilius M, Stonys J (2016) Laikino nuosavybès teisiu apribojimo problematika baudžiamajame procese: optimalaus sprendimo beieškant. In: Švedas G (ed) Baudžiamoji justicija ir verslas. Vilniaus universiteto leidykla, Vilnius

Goda G, Kazlauskas M, Kuconis P (2011) Baudžiamojo proceso teisè. Registrų centras, Vilnius

Misiūnas A, Rimkus V (2007) Preconditions and consequences of illegal goods traffic. Intelektinè ekonomika, No. 2(2)

Šatienė G, Baltrūnienė J, Jokšas L (2011) Kontrabandos ir korupcijos kaip socialinių reiškinių santykis. Ekonomika ir vadyba: aktualijos ir perspektyvos, 3(23)

Švedas G (ed) (2004) Lietuvos Respublikos baudžiamojo kodekso komentaras. Bendroji dalis (1-98 straipsniai). Teisinès informacijos centras, Vilnius

Švedas G (2011) Kai kurie probleminiai juridinio asmens baudžiamosios atsakomybès aspektai Lietuvos konstitucinejje jurisprudencijoje ir baudžiamosios justicijos doktrinoje. In: Švedas G (ed) Lietuvos Respublikos baudžiamajam kodeksui - 10 metų. Registrų centras, Vilnius

\section{Online Sources}

Giriūnaitė A (2018) Nepajègiant užsukti kontrabandos čiaupu Lietuvoje skelbiama apie naujas priemones. https://www.lrytas.lt/verslas/rinkos-pulsas/2018/12/16/news/nepajegiant-uzsuktikontrabandos-ciaupu-lietuvoje-skelbiama-apie-naujas-priemones-8378251. Accessed 16 Apr 2020

Ignotas P (2018) Tabako gamintojai: "Cigarečių pakuočiu suvienodinimas tik padidins kontrabandą". https://www.lrytas.lt/verslas/rinkos-pulsas/2018/11/02/news/tabako-gamintojaicigareciu-pakuociu-suvienodinimas-tik-padidins-kontrabanda\%2D\%2D8078976/. Accessed 16 Apr 2020

Kazakevičius K (2018) Rūkalu kontrabanda: skaičiai disonuoja. https://www.lzinios.lt/Lietuva/ rukalu-kontrabanda-skaiciai-disonuoja/261510. Accessed 16 Jan 2020

Sinkevičius D (2015) Niekam neprilygstančios gaujos byla: patyrè milijoninius nuostolius. https:// www.delfi.lt/news/daily/crime/niekam-neprilygstancios-gaujos-byla-patyre-milijoniniusnuostolius.d?id=67321544. Accessed 16 Apr 2020

Steniulienė I (2019) Karaliaus kontrabandos byla: prašo priteisti per 4,8 mln. eurų muitinei. https:// www.delfi.lt/news/daily/law/karaliaus-kontrabandos-byla-praso-priteisti-per-4-8-mln-eurumuitinei.d?id=80919381. Accessed 16 Apr 2020 
Gintaras Švedas Ph.D., is Professor of criminal law at the Faculty of Law of the University of Vilnius, Lithuania. He has been Head of Criminal Justice Department of Law Faculty of Vilnius university (from 2003), Professor of law at Law Faculty of Vilnius university (from 2009); ViceDean for Planning and Sciences of Law Faculty of Vilnius university (from 2006); Member of the Committee of the Criminal Code Supervision under the Ministry of Justice (from 2012); Contact point for Lithuania in the European Criminal Law Academic Network (ECLAN) (from 2006) and Member of Management Committee of ECLAN (from 2018); Member of the Committee on Legal Reform in Ukraine (from 2019). As a Lithuanian national expert, he took part in numerous international scientific projects. Professor Švedas has held many public offices. He was ViceMinister of Justice of Lithuania in the years 1993-2006, Agent of the Government of the Republic of Lithuania to the European Court of Human Rights (1995-2003), Member of the Management Board of Fundamental Rights Agency (2007-2010), Public Adviser to the Minister of Justice in the fields of criminal law, enforcement of punishments, implementation of the EU law (2012-2016). Professor Švedas authored and coauthored 9 monographs, 85 scientific articles, 21 manuals, textbooks and educational works, 11 compendiums. He also was involved in preparation of, among others, the Criminal Code, Code of Punishment Enforcement and Code of Criminal Procedure of the Republic of Lithuania.

Open Access This chapter is licensed under the terms of the Creative Commons Attribution 4.0 International License (http://creativecommons.org/licenses/by/4.0/), which permits use, sharing, adaptation, distribution and reproduction in any medium or format, as long as you give appropriate credit to the original author(s) and the source, provide a link to the Creative Commons licence and indicate if changes were made.

The images or other third party material in this chapter are included in the chapter's Creative Commons licence, unless indicated otherwise in a credit line to the material. If material is not included in the chapter's Creative Commons licence and your intended use is not permitted by statutory regulation or exceeds the permitted use, you will need to obtain permission directly from the copyright holder.

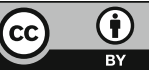

